\title{
Orogen-parallel brittle extension as a major tectonic imprint in the Neogene evolution of the Southwestern Alpine arc
}

\author{
Romain Beucher ${ }^{1}$, Christian Sue ${ }^{2}$ and Pierre Tricart $^{3}$ \\ ${ }^{I}$ School of Earth Science, University of Melbourne, Melbourne, VIC, Australia \\ rbeucher@unimelb.edu.au \\ ${ }^{2}$ CNRS-UMR6249, Bourgogne Franche-Comté University, Besançon, France, \\ christian.sue@univ-fcomte.fr
}

${ }^{3}$ ISTerre, Université Grenoble Alpes, Grenoble, France, ptricart@cegetel.net

\begin{abstract}
We present a new analysis of the late Alpine brittle deformation in the southern branch of the Western Alpine arc, focusing on the stack of internal metamorphic nappes east of the Argentera external crystalline massif. The regional-scale fault network is dominated by a NW-SE striking right-lateral fault system that follows the general curvature of the arc and controls the overall morphology of the area. A second fault set strikes N-S and is mainly represented by normal faults which accommodate orogen-parallel extension. Structural analysis and paleostress tensors derived from inversion of fault-slip data reveal a complex pattern of deformation involving extensional and strike-slip deformation events. The orogen-parallel extension previously described in the internal zones at the east of the Pelvoux massif is confirmed further south and we show that it is combined with right-lateral strike-slip deformation that increases in intensity towards the southwest. The stability of the minimum stress axis $(\sigma 3)$ direction suggests that extensional and transcurrent regimes are contemporaneous and highlights regional interferences between inner brittle extension, parallel to the strike of the belt, and the strike-slip strain field driven by the
\end{abstract}


counterclockwise rotation of the Apulia-Adria plate. The curved geometry of the belt constrains the direction of extension and the coupling relationship between the internal and external Alpine zones. We propose that the Neogene tectonic history is a result of the unique curved tectonic architecture of the South-Western Alps with respect to the rotation of the Apulia-Adria indenting plate. The southern tip of the Western Alpine arc represents a transitional zone between extension in the inner chain and strike-slip/compression in the outer parts.

\section{- INTRODUCTION}

The tectonic and orogenic evolution of the Alps has been dominated by the indentation of the European margin by the Apulia-Adria African promontory since the Eocene (see Tapponnier, 1977; Handy et al. 2010;

Schmid and Kissling, 2000 for review). The structure of the belt is classically divided between highly deformed and metamorphosed 'internal zones' which contrast with the less shortened and low-grade metamorphic 'external zone' (e.g. Bousquet et al. 2008) (Figure 1). The characteristic arcuate shape of the Western Alps was acquired during the Oligocene, partly resulting from the palaeogeography of the Apulia-Adria indenter and from complex rotations and shearing within the internal zone relative to a stable Europe (Goguel, 1963; Gidon, 1974; Debelmas, 1986; Ménard, 1988; Vialon et al. 1989; Laubscher, 1996; Collombet et al. 2002).

All along the European Alps compressional structures observed in the internal zones are overprinted by late brittle faults linked to complex extensional and transtensional deformation with a general direction of extension that follows the curvature of the belt (Bauve et al. 2014; Bertrand et al., 2015; Bertrand and Sue, 2017; Bistacchi and Massironi, 2000; Champagnac et al. 2003; Champagnac et al. 2004; Champagnac et al. 2006; Ciancaleoni and Marquer, 2008; Grosjean et al, 2004; Kurz et al. 1993; Perrone et al. 2011; Sue and Tricart, 1999; Sue and Tricart, 2002; Sue and Tricart, 2003b; Sue et al. 1999; Sue et al. 2007; Wang and Neubauer, 1998) (Figure 1).

Analysis of the relationship between fault rocks, hydrothermal veins and the thermal history determined by fission track thermochronometry in the NW-Alps showed that the transition from ductile to brittle deformation occurred at different times, with transitions occurring during the Eocene-Oligocene and during the OligoceneMiocene (Malusa et al. 2009). It has been proposed that the extensional tectonic phase took place during the Neogene, immediately after the Oligocene climax of collision, and represents a late tectonic event in the alpine 
history (e.g. Sue and Tricart, 2003b; Allanic, 2012; Zwingmann and Mancktelow, 2004).

In detail, the Neogene orogen-parallel extension recognized at the scale of the Alpine chain as a whole has been followed by a still active orogen-perpendicular extension well described in the Western arc of the Alps. Analysis of the present-day displacement field derived from geodetic and seismotectonic data reveals that the internal zones are still undergoing extensional deformation showing a preferential direction of extension perpendicular to the belt axis (review in Delacou et al. 2004; Sue et al. 2007) which indicates a Plio-Quaternary

(Sue et al. 2007) switch from orogen-parallel extension. The origin of the latest extensional deformation results from complex vertical motions in the alpine crust but the exact nature of the structures and associated dynamics remain a matter of debate (e.g. Sue et al. 2007; Vernant et al. 2013; Chéry et al., 2016; Fox et al. 2015; Schlunegger and Kissling, 2015; Zhao et al. 2015; Nocquet et al. in press.; Champagnac et al. 2007; Serpelloni et al. 2013; Baran et al., 2014).

The apparent link between the arcuate shape of the belt and the directions of extension draws interest towards the southern termination of the arc, where the strike of the belt quickly changes from N-S to WNW-ESE. The area stands out as an essential element to understanding the genesis of the Alpine arc's bend in its latest evolutionary stages, including the transition in the pattern of deformation. Recent neotectonic investigations have focused on the Argentera crystalline massif and the easternmost part of the external zone (Sanchez et al. 2010; Bauve et al. 2014).

Here we detail the late brittle deformation in the stack of the internal metamorphic nappes east of the Argentera external crystalline massif (Figure 2) and we discuss the Neogene brittle deformation of the area and its regional significance. Our contribution focuses on the geometry of the fault array at local to regional scales and on the corresponding palaeostress fields quantified from the inversion of fault/striae measurements. We aim to gain a better understanding of the late deformation stages affecting the Western Alpine arc and their relationships to the overall arcuate shape of the belt.

\section{- GEOLOGICAL AND TECTONIC SETTING OF THE SW WESTERN ALPS}

\section{Geological and tectonic setting}

The southern part of the Alpine arc is characterized by several zones with complex deformation histories 
since the Oligocene (Figure 2).

The internal metamorphic zones, to the east, comprise the Briançonnais zone, a stack of margin-derived nappes, and the overriding Piémont zone, a more complex imbrication of nappes derived from the distal margin and the Téthyan Ocean (e.g. Graciansky et al. 2010). These nappes were mainly stacked during a Late-Cretaceous to Eocene E-W compression phase, in an oceanic accretionary wedge evolving into a collision wedge and experiencing HP-LT metamorphic conditions (Frey et al. 1999; Schwartz et al. 2000; Lanari et al. 2012; Lanari et al. 2014; Agard, 2001; Mohn et al. 2010). This wedge was severely and repeatedly refolded during the Oligocene, as it was thrust over the external zone along the Crustal Penninic Front (CPF (Sue and Tricart, 2003b)) at c. 32 Ma to 35 Ma (Simon-Labric et al. 2009) and a collision wedge was built at the scale of the entire present day Alpine realm (e.g. Tricart et al. 2006). From the Neogene onwards, deformation in the inner part of the arc was driven by large NW-SE to WNW-ESE strike-slip right-lateral fault systems which accommodated rotations and indentation of the ApuliaAdria indenter (review in Collombet et al. 2002).

The major ophiolitic complex in the Monviso massif underwent eclogitic metamorphic conditions around 45-50 Ma (Rubatto and Hermann, 2003; Duchêne et al. 1997). In the same massif, a ZFT age of 19.6 Ma and an AFT age of 8.6 Ma indicate a mean cooling rate of $15-19^{\circ} \mathrm{C} / \mathrm{Ma}$ that leads to a $0.6-0.8 \mathrm{~km} / \mathrm{Ma}$ estimation of the exhumation rate during Miocene times if one assumes a $25^{\circ} \mathrm{C} / \mathrm{Km}$ gradient (Schwartz et al. 2007).

In Queyras and Upper Ubaye, ZFT system has not been completely reset (Schwartz et al. 2007) although metamorphism reached the blueschist facies between 45 and 62 Ma (Agard et al. 2002). In the same regions, the AFT ages range between 22 and $26 \mathrm{Ma}$, characterizing a trend to younger exhumation from west towards east during the Miocene. Tricart et al. (2007) emphasize that the transverse gradient is the opposite of what is observed in the Piedmont area further north in the Western Alps, indicating a unique later thermal history for the southern branch of the arc.

The ZFT system has not been reset in the Brianconnais units having undergone high pressure greenschist metamorphic conditions around 43-50 Ma (Bucher, 2003). The AFT ages are Oligocene, ranging between 22.2 \pm 1.6 and 31.7 \pm 2.0 Ma. These ages appears remarkably old with respect to those obtained by Seward and Mancktelow 
(1994) further north, and seems to indicate a trend to older ages towards the south (Tricart et al. 2007).

At the southern tip, the Briançonnais zone, belonging to the Ligurian Alps and close to the Mediterranean Sea, yielded a ZFT age of 31 Ma (Vance, 1999) which suggests that the whole southern part of the Briançonnais arc was cooled recently. The AFT ages between 24 and 26 Ma (Barbieri et al. 2003, Carrapa et al. 2003) confirm this important observation, and is consistent with the transgression of the Oligocene molasses on the Ligurian Briançonnais around $30 \mathrm{Ma}$ (Molare Formation, see Gnaccolini et al. 1998). This element highlights the contrast between the northern and southern branches of the Western Alps as regards to the thermal evolution of late-collision stages. The southern branch appears to have undergone an early exhumation history.

To the west of the studied area, ocean-derived 'Exotic Flysch' nappes override the internal fringe of the external zone. These non-metamorphic nappes of internal origin were emplaced at shallow levels just before crustalscale underthrusting below the CPF (Tricart, 1984). They presently lie in a structural saddle between the Pelvoux and Argentera elevated massifs (Ménard, 1979), interpreted by (Sanchez et al. 2010) as a recent and still active pullapart structure connected to the north with the dextral Jausiers Fault where significant seismic activity was recently recorded (Jenatton et al. 2007). The External zone, represented here by the Mesozoic to Cenozoic sedimentary cover of the Pelvoux and Argentera crystalline basement, was deformed during the E-W compression phase and then subject to N-S compression during the Miocene (e.g. Giannerini et al. 2011; Laurent et al. 2000). This style of deformation would be still active during the Pliocene as suggested by the dextral strike-slip reactivation of thrust faults in the foreland sedimentary cover (e.g. Bauve et al. 2012; Hippolyte and Dumont, 2000).

To the Southeast, the Argentera crystalline massif results from uplift of the Variscan basement in association with reverse and strike-slip faulting along NW-SE lineaments (e.g. Bigot-Cormier et al. 2006; Bogdanoff et al. 2000). The compression direction is assumed to have rotated from NE-SW to N-S during the late Miocene-Pliocene explaining evolution of SW-verging reverse faults into dextral transpressive faults (Bellahsen et al. 2012; Dumont et al. 2012; Ford et al. 2006; Schreiber et al. 2011). The Cretaceous to Tertiary sedimentary cover around the massif has undergone recent normal faulting (Labaume et al. 1989; Sanchez et al. 2010). Several stages of mid-crustal greenschist facies brittle-ductile shear zone activity related to N-S shortening have been dated at 26, 22 and $20 \mathrm{Ma}$ (Corsini et al. 2004; Sanchez et al. 2011b). Apatite fission-track analyses from Bigot-Cormier et al. (2006) and 
Sanchez et al. (2011) show a transition from ductile to brittle deformation in the crystalline basement at around 12 Ma consistent with the N-S compression (Baietto et al. 2009; Sanchez et al. 2011a; Sanchez et al. 2011 b).

Both the CPF and the drainage divide follow the mountain belt curvature, trending NW-SE to the NW of the Argentera massif and W-E to the east of this massif (Figure 2). This curvature is also displayed by an important corridor of brittle fault zones. Among them is the NW-SE Serenne-Bersezio fault recognized early on as a major dextral fault (Sturani, 1962; d'Atri, 2016). To the North, the Serenne-Bersezio fault zone extends into the High Durance fault zone that trends N-S, behind the Pelvoux crystalline massif (Sue and Tricart, 2003b with ref. therein).

\section{Active Tectonics}

The Southwestern Alps are considered the most seismically active part of the Alps with some of the largest instrumental events recorded (Ubaye, 05-04-1959, ML=5.5) (Ménard, 1988; Sue et al. 2007; Jenatton et al. 2007). Historical earthquakes catalogue report Medvedev - Sponheuer-Karnik (MSK) intensity up to X and estimated magnitude higher than 6 (Lambert and Levret-Albaret, 1996). The seismicity affects both the internal and external zones. Several faults have been recognized as being seismogenic or potentially seismogenic and usually correspond to inherited Alpine structure at depths down to $15 \mathrm{~km}$ (Lardeaux et al. 2006; Schreiber et al. 2010, Sue et al. 2007) ; The High-Durance Fault is known to be active since the Miocene and reactivates the CPF in extension (e.g. Sue et al. 2007, 2010). Seismic activity is documented on both NS to NE-SW and NW-SE faults: Earthquake swarms have recently been recorded in the vicinity of the NW-SE Jausiers Fault (Jenatton et al. 2007) revealing complex dextral strike-slip and extensional accommodation of the deformation. NW-SE faults such as the Serenne-Bersezio fault have been affected by earthquakes with dextral strike-slip mechanisms (Sue et al. 1999), while N-S to NE-SW faults show left-lateral and normal displacements (Moyenne Durance fault: Sébrier et al. 1997; Peille-Laghet fault: Courboulex et al. 2003).

\section{- METHODS}




\section{- Morphotectonic analysis}

The regional lineaments were investigated through morphotectonic analysis of shaded digital elevation models (30m resolution) together with observation of aerial photographs and geological maps. This approach remains qualitative and is suitable for identifying the dominant directions characterizing the fault network. It has been validated through repeated comparison with observations in the field.

\section{- Structural Analysis in the Field}

The current tectonic structure of the area is the result of a complex series of tectonic phases which occurred before and during collision. Structural analysis of outcrops in the field allowed the late-stages of alpine brittle deformation to be resolved from earlier compression-related structures such as nappe piles, folds, schistosities and cleavages related to the different compressional phases. Here we focus essentially on the late brittle stages of deformation and do not consider the pre-alpine phases nor later phases related to nappe tectonics. However, as each of those phases may have strongly influenced the following, we performed a careful structural analysis to assess the role of inherited structure on the brittle deformation stages.

In the following, a 'site' is defined as an outcrop area of ca. $1 \mathrm{~km}^{2}$ with homogenous lithology. Outcrops mainly comprise Triasic-to-Cretaceous carbonates and marly series derived from the ocean and metamorphosed during the alpine history. Senses of slip on the fault planes were determined in the field from offset markers, striae, grooves, and/or fibers, and en-échelon structures; in that frame, high confidence slip sense indicators were used to validate lower confidence indicators in the vicinity. Several sites presented superimposed brittle deformation structures whose relative chronology has been determined from crosscutting relationships.

\section{- Paleostress Tensor Inversion}

The determination of regional stresses from populations of fault-slip data is based on the Wallace and Bott hypothesis (Bott, 1959; Wallace, 1951) that considers several assumptions: (1) the shear stress vector applied to a given fault is parallel to the slip vector along the fault surface; (2) the fault surfaces are planar; (3) the blocks are rigid; (4) no stress perturbation exists, i.e. movements of faulted blocks are free; and (5) a steady stress state prevails 
during a given tectonic event. The inversion of fault-slip data is consequently not a trivial problem and has to be carefully carried out and systematically associated with a structural field analysis.

Several methods have been developed and discussed in previous publications and we refer you to these for a complete discussion (e.g. Angelier, 1984; Angelier, 1990; Etchecopar et al. 1981; Yamaji, 2000; Yamaji, 2002;

Lacombe, 2012).

In this work, the inversions of fault-slip data have been carried out using the direct inversion method (Angelier, 1990) implemented in the TectonicsFP software (Ortner et al. 2002). Each inversion of a subset of data resulted in a best-fitting reduced stress tensor (Angelier, 1984) defined by the orientation of the three principal stress axes, $\sigma 1, \sigma 2$, and $\sigma 3$ (with $\sigma 1>\sigma 2>\sigma 3)$, the $\varphi$ ratio $(\varphi=(\sigma 2-\sigma 3) /(\sigma 1-\sigma 3))$ representing the shape of the stress ellipsoid and the average misfit angle $\alpha$, which is the angle between the measured striae and the computed shear stress vector. The $\varphi$ value, which ranges from 0 to 1 , indicates the relative magnitudes of the principal stresses and consequently the susceptibility of palaeostress axes to perturbations, and its own stability. The misfit angle represents an estimate of the coherency of the fault-slip population: individual faults with misfit angles greater than $30^{\circ}$ have been considered as unrelated to the considered stress tensor and discarded. In demonstrably polyphase sites (in the field), palaeostress tensors related to the subsequent stages were computed independently without using automatic separation of data.

The result of the direct inversion was subsequently compared to results obtained with other methods of palaeostress determination: the right dihedral solution (RD) (Angelier and Mechler, 1977), the pressure-tension method (PBT) (Turner, 1953), and the numerical dynamic analysis (NDA) (Spang, 1972) for a $30^{\circ}$ angle $\theta$ according to the Anderson theory of faulting (Anderson, 1951). The parameters obtained for each of the four methods are provided as supplementary data. Tensors with fewer than 8 faults were systematically discarded. Using these criteria, $85 \%$ of the 1700 total fault-slip measurements have been used in the paleostress inversion process.

\section{- RESULTS}

\section{•}

- Morphotectonics

Distribution of fault strike directions derived from the morphotectonic analysis of aerial photographs and 
DEM allow the identification of three main directions (Figure 3):

The first is a NW-SE (trending $\mathrm{N} 140^{\circ} \mathrm{E}$ to $\mathrm{N} 150^{\circ} \mathrm{E}$ ) set of faults. The lineaments were recognized in the field as dextral second-order faults associated with the major NW-SE Bersezio fault. These faults govern the morphology of the area, which is characterized by alignments of NW-SE dry glacial valleys (Figure 4A and 4B). The second set of faults defines an N-S oriented subset, identified in the field as mainly normal faults defining tilted blocks (Figure 4C) or steep conjugate fault sets (Figure 4D) that can accommodate orogen-parallel extension. The third, relatively minor, fault set was identified with a NE-SW trend (trending $\mathrm{N} 30^{\circ} \mathrm{E}$ to $\mathrm{N} 40^{\circ} \mathrm{E}$ ) and is correlated with sinistral or normal faults, conjugated with the main family.

\section{- $\quad$ Field analysis}

Structural analysis of outcrops in the field reveals multiple lines of evidence for extensional and strike-slip deformation:

The Mount Arpet site (Figure 5) shows numerous pairs of close to N-S trending steep faults with opposite dips, likely representing conjugate normal faults (Anderson, 1951). Their extensional character is confirmed by the normal slip sense indicated by striae, slickenfibers and en-échelon tension gashes associated with most faults. Slip directions mainly display high pitch values confirming E-W horizontal extension. The fault/striae measurements along the outcrop allowed computation of a first palaeostress tensor that is consistent with an E-W extension (horizontal minimum compressive stress direction, $\sigma 3$, trending $093^{\circ}$ ). Normal faults have been subsequently reactivated as strike-slip faults, as evidenced by nearly horizontal late striae. This second population of fault/striae measurements lead to a palaeostress tensor that displays horizontal N-S $\sigma 1$ and E-W oriented $\sigma 3$ (respectively $\mathrm{N} 10^{\circ} \mathrm{E}$ and $\mathrm{N} 100^{\circ} \mathrm{E}$ ) axes. Note that both tensors exhibit a similar $\sigma 3$ direction.

Another characteristic example comes from the NW-SE striking Fouillouse Valley (Figure 6) which follows the northward trend of the Serenne fault zone that links the Upper Durance fault zone to the North and the Bersezio fault zone to the southeast (see Sue and Tricart, 2003a; Tricart, 2004 for details). A large N130-140 ${ }^{\circ} \mathrm{E}$ fault surface

is exposed along an outcrop of several tens of square metres. The nearly vertical surface shows metre-scale tectonic grooves that dip close to horizontal. They indicate a major dextral strike-slip displacement. These grooves are 
overprinted by a second generation of grooves characterized by shorter wavelengths and that plunge moderately towards the SE, in response to an evolving tectonic regime. Locally, final movement along the fault is indicated by sub-vertical striae, associated with pressure-dissolution features on the flanks of the pre-existing horizontal grooves. This third movement is confirmed by dragfolds that affect the pre-existing cataclastic zone. Our analysis clearly indicates down-throw to the North-East along the fault in a tectonic regime evolving from strike-slip (transcurrent displacement) to normal slip (extensional displacement). As inversion of fault/striae pairs is not applicable to multiple measurements along a single fault surface, we did not invert this data. However, measurements allow a graphical estimation of the principal compressive and tensional axes using the right-dihedra method as proposed by (Angelier and Mechler, 1977). This procedure leads us to propose a continuous evolution of slip along the fault surface, from pure right-lateral strike-slip through an increasing oblique movement, ending by the collapse of the northern compartment, in a roughly E-W extensional regime.

The analysis of multiple sites across the studied area revealed that the fault network has been reactivated several times. The N-S and NE-SW faults are clearly related to extension but show many evidences of strike-slip reactivations while the NW-SE faults (Serenne-Bersezio fault system), which are clearly related to dextral strike-slip movements, also accommodate extensional deformations. If chronologies can be established locally, the succession of regimes at the regional scale is more ambiguous which suggests that the extensional and strike-slip deformations observed in the area are the expression of complex interactions between the stress regime and the local structures. The alternating transcurrent and extensional regimes remain everywhere consistent with a roughly E-W striking $\sigma 3$ axis, which appears as the most stable regional tectonic feature.

\section{- Statistical Analysis of Fault/Striae pair measurements and Paleostress Determination}

A total of 1700 fault-striae pairs have been measured in 60 sites throughout the study area. Azimuthal distribution of the complete fault measurements dataset (Figure 7) shows NW-SE to NE-SW oriented faults with a dominant N-S orientation. The azimuths are comparable to those derived from the lineament analysis (Figure 4) and the dataset is consequently considered as representative of the regional fault pattern. The faults are generally steep, with about $70 \%$ of the dataset showing dips greater than $60^{\circ}$.

The inversion of fault-slip data allowed to reconstruct 79 reduced paleostress tensors at the regional scale 
(stereonets and associated parameters are presented in Supplementary material). In the following, the stress tensors are described in terms of tectonic regime based on the dip of the principal stress axis: compressional regime ( $\sigma 3$ steeper), extensional regime ( $\sigma 1$ steeper) and strike-slip regime ( $\sigma 2$ steeper).

The Frohlich triangular diagram (Frohlich, 1992) shows the distribution of the stress tensor in terms of tectonic regimes with the three vertices representing pure 'Andersonian', strike-slip, extensional and compressional regimes (Figure 8). The tensors are essentially distributed between extensional (51\%) and strike slip regimes (47\%). The highest density of tensors occurs close to the extensional vertex near a position where the $\sigma 1$ axis plunges between $60^{\circ}$ to $90^{\circ}$ and $\sigma 2$ and $\sigma 3$ plunges by less than $30^{\circ}$. In general, resulting stress tensors are away from pure extensional and pure strike-slip ‘Andersonian’ positions. The strike-slip tensors uniformly cover the strike-slip domain and do not show any particular clustering.

The same kind of observation can be drawn from the analysis of the $\varphi$ ratios (Figure 8). About one half of the extensional tensors presents $\varphi$ ratio value lesser than 0.5 (34\% have $\varphi$ ratio lesser than 0.25$)$ and suggests a tendency to radial extension. The $\varphi$ ratio values of the strike slip tensors are more distributed but $66 \%$ have $\varphi$ ratio lesser than 0.5 , associated with pure strike-slip and transpression.

Azimuthal distribution of paleostresses direction (Figure 9) shows $\sigma 1$ axes mainly oriented N-S and a minor peaks at $\mathrm{N} 20^{\circ}$ to $30^{\circ} \mathrm{E}$, keeping in mind that the $\sigma 1$ are subvertical for the extensional tensors. A striking aspect is the relatively stable direction of the $\sigma 3$ axis for both extensional and strike-slip tensors $\left(\mathrm{N} 70^{\circ} \mathrm{E}\right.$ to $\left.120^{\circ} \mathrm{E}\right)$. The map presented in figure $9 \mathrm{~B}$ shows the projected direction of the minimal horizontal stress axis $\sigma 3$ for the strike-slip and extensional stress tensors $\left(\mathrm{N} 100^{\circ} \mathrm{E}\right)$. The overall map shows coherency between the extensional and strike-slip minimal stress axis directions. The directions follow globally the trend of the arc of the Western Alps which highlights a primary control from the regional structure, but significant deviations with respect to the local direction of the CPF $\left(>30^{\circ}\right)$ are observed in places and suggest local perturbations of the stress regime. There is no clear regionalization between strike-slip and extensional tensors and both of them uniformly cover the whole studied area. The local obliquity between faulting directions and stress axes, if significant, may explain oblique movements observed in the field. This also echoes with the tendency to radial extension drawn from the analysis of the $\varphi$ ratios and points towards interaction between the stress regime with the pre-existing local structures. As a whole, the arcuate shape of the belt and pre-existing alpine structures seems to control the tectonic expression of the stress regime deduced from brittle deformation analysis. 


\section{- DISCUSSION}

\section{-}

We discuss our results in the light of the stress regimes derived from previous studies in the overall Southwestern Alps (Figure 10), namely to the North of the present study in the Briancon region, east and southeast of the Pelvoux crystalline massif (Sue, 1998; Sue and Tricart, 2003a) and to the southwest in the sedimentary cover of the Argentera crystalline massif (Bauve et al. 2014). We then integrate those results in the regional tectonic context and discuss the main factor controlling the Southwestern Alps's tectonic evolution.

The multi-scale analysis of the brittle deformation affecting the internal zones of the SW Alps presented in this study reveals a complex pattern which involves both strike-slip and extensional deformations. The three main fault orientations documented here $\left(\mathrm{N} 140^{\circ}\right.$ to $150^{\circ} \mathrm{E}, \mathrm{N} 0^{\circ}$ to $10^{\circ} \mathrm{E}$, and $\mathrm{N} 30^{\circ}$ to $\left.40^{\circ} \mathrm{E}\right)$ are comparable with those identified in the sedimentary cover of the Argentera (Bauve et al. 2014; Sanchez et al. 2010). They are also consistent, although slightly deviated, with the faults identified in the Upper Durance Valley to the North (Sue, 1998; Sue and Tricart, 2003a). The slight differences with respect to the directions observed further north are interpreted as related to the general curvature of the belt. The NW-SE oriented faults mainly accommodate dextral deformations along the curvature of the arc while N-S faults accommodate extension parallel to the main axis of the chain. Multiple evidences of oblique movements on the fault planes reveal that the fault network has been reactivated several times during the Neogene to accommodate switches between extensional and strike-slip regimes, both of them keeping the same overall $\sigma 3$ axis' strike $\left(\mathrm{N} 100^{\circ} \mathrm{E}\right)$.

The strike-slip tensors show a remarkably constant N-S direction of the principal stress axis $\sigma 1$ which is consistent with the regional direction of compression resulting from the Europe-Apulia convergence and the counterclockwise rotation of Apulia-Adria. The latter clearly controls the overall right-lateral shear between the internal and external zones and account for the local N-S direction of compression (e.g. Calais et al. 2002). It is also clearly related to the compressional and strike-slip structures observed in the Mesozoic and Cenozoic cover of the External domain south of the studied area (Giannerini et al. 2011; Gigot et al. 1974; Laurent et al. 2000; Gidon, 2000).

Extensional indicators previously described further north in the High Durance (Sue and Tricart, 2002; Sue 
and Tricart, 2003a) and up to the Aosta Valley (Champagnac et al. 2004; Champagnac et al. 2006; Sue et al. 1999) are confirmed in the internal zones of the SW Western Alps. Our study also links the extension in the internal zone to the extension observed in the North-Western part of the Argentera massif (Sanchez et al. 2010; Bauve et al. 2014). Our study reveals a clear southward continuity of extensional deformation but highlights an increasing importance of dextral strike-slip deformation from the east of the Pelvoux to this NW-SE oriented part of the internal Alpine arc. In addition, contrary to the Pelvoux transect, both dextral slip and extension also affect the inner fringe of the external zone, in particular the Argentera massif (Sanchez et al. 2010 with references therein).

A major issue in constraining the paleostress-axis in time comes from the inherent difficulties in dating activation of faults within the area. Previous works in the NW-Alps have successfully combined analysis of paleostress-axis with fault-rock types and thermochronological data (Malusa et al. 2009; Bertrand et al, 2015). We attempted to sample and extract apatites but the nature of rocks constituting the terrain of the study area did not prove suitable for thermochronological analysis (Beucher et al., 2009). They are mainly constituted by carbonates and very marly series derived from the oceanic domains metamorphosed into marble or calcshists (the so-called Shistes Lustrés). No-direct evidences allow for a precise chronology of deformations and more work is needed to constrain the Neogene history of the Southwestern Alps. However, the structural analysis of the outcrops, the orientation of the principal stresses of the tensors which generally deviate from 'Andersonian' positions and the contradictory chronologies across the studied area suggest that the transition between strike-slip and extensional deformation is progressive, with potential switching between these two end-members. This lead us to question the validity of discussing the Neogene evolution of the SW Alps in terms of phases and to consider, as already proposed further south by (Bauve et al. 2014), that strike-slip and extensional deformations are contemporaneous and potentially related to the interaction of a single tectonic regime with the local structures. This remains compatible with the evolving state of stress proposed further north by (Sue et al. 1999; Sue and Tricart, 2002; Sue and Tricart, 2003a), which highlighted radial (i.e. multi-trend) extension affecting the internal metamorphic zones east of the Pelvoux massif and subsequent transcurrent deformation. Indeed, in the overall Southwestern part of the Alpine arc, we established the preponderance of orogen-parallel extension (mean strike for the $\sigma 3$ axes of N101 ${ }^{\circ} \mathrm{E}$ ) (Figure 10), with respect to the mix between orogen-perpendicular and parallel extension recognized to the North (Sue and Tricart, 2003b), with mean $\sigma 3$ axes $\mathrm{N} 160^{\circ} \mathrm{E}$ (CS-North, Figure 10) and $\mathrm{N} 115^{\circ} \mathrm{E}$ (CS-South, Figure 10) from North to 
South for the orogen-parallel component, and $\mathrm{N} 84^{\circ} \mathrm{E}$ for the orogen-perpendicular one (Figure 10) (see also Champagnac et al. 2006). This orogen-parallel component remains surprisingly stable all along the SW branch of the Alpine inner arc. Moreover, we found a very similar tectonic pattern as the one established to the Southeast by Bauve et al. (2014), whose data show a N95 E mean $\sigma 3$ strike (VB, Figure 10). Regarding the paleostress field published by Bauve et al. (2014) and our own results, it seems that the importance of extensional tectonics increases from west to east with respect to transcurrent tectonics, along a transect cutting through the north of the Argentera crystalline massif, from its external cover to the internal zones (Figure 10).

The statistical distribution of our $\varphi$ stress ratios displays a primary signal with low $\varphi$-ratio $(<0.25)$, for a majority of the extensional tensors and a significant number of the strike-slip tensors, which implies close magnitudes of the $\sigma 2$ and $\sigma 3$ axes. This may explain the local variations of the $\sigma 3$ axes observed on the map (Ritz, 1992). However, the stability of the $\sigma 1$ and the $\sigma 3$ direction shows that the transitions between dominant extensional and strike slip regimes require a permutation of the principal stress axes $\sigma 1$ and $\sigma 2$ around a constant $\sigma 3$.

The last and still active radial extensional regime affecting the Western Alps has been recognized for over a decade both through seismotectonic and palaeostress analyses (Baroux et al. 2001; Champagnac et al. 2003; Champagnac et al. 2004; Delacou et al. 2004; Eva et al. 1998; Selverstone, 2005; Sue et al. 2007; Sue et al. 1999; Sue and Tricart, 1999; Sue and Tricart, 2002). The area undergoing current extension corresponds in map to the high chain and to the thickest crust in the Alps (high elevation and deep Moho) (Sue et al. 2007; Larroque et al. 2009). This still active extension is also linked to the current rapid uplift of the Western Alps and related exhumation, and has been proposed to be due to gravitational potential adjustments within the West-alpine crustal and/or lithospheric root (Sue et al. 2007; Champagnac et al. 2007; Vernant et al. 2013; Serpelloni et al. 2013; Fox et al. 2015; Baran et al. 2014; Schlunegger and Kissling, 2015; Zhao et al. 2015; Chéry et al. 2016; Nocquet et al. 2016).

In an attempt to explain the prior Neogene orogen-parallel extensional pattern in the internal Western Alps, several studies (Sue et al. 2007; Champagnac et al. 2006) have proposed that the opening of the Ligurian Sea during Miocene times would act as a free boundary and would have allowed the extension to the Southeast, coeval with an ongoing plate indentation. However, the timing between the onset of extension in the Alps together with the opening of the Ligurian Sea and the formation of the arcuate geometry remains poorly constrained. It is, however, likely that the orogeny in the Apennines (25-0 Ma) and the 50 counterclockwise rotation of the Corsica-Sardinia block and the 
Ligurian Alps (Maffione et al., 2008) have further accentuated the arc of the Western Alps at its southern tip (Schmid et al., 2016). A recent study of the seismic anisotropy within the upper-mantle revealed that the NW-SE direction which underlines the arcuate shape of the belt and characterizes the southern part of the Western Alps is also observed within the mantle (Barruol et al. 2004; Qorbani et al. 2015). This implies a coupling between the upper-crust and the upper-mantle but also suggests that the internal structure of the belt may be controlled by the mantle flow underneath the southern part of the Alps. Indeed, such a scheme with orogen-parallel normal faulting developed in the core of an active collision belt has been described in other geodynamic contexts, such as in Himalaya (Seeber and Pêcher, 1998), and could be a systematic response of the upper crust in internal zones of a collision chain.

In our tectonic scheme, it appears that the arcuate shape of the belt strongly controls the direction of extension. As similar deformations also affects the inner fringe of the external zone, we propose a partial coupling between the external and internal arcs. The extensional deformation quickly fades out as we go further south and west into the External zone where the deformations are mainly compressional or transcurrent. This tends to confirm that the extension rises up from processes internal to the chain. Indeed, the southern branch of the alpine arc has a unique situation in the Alps as it shows interferences between local gravity-driven extensional pattern likely related to internal re-equilibration of the belt with a more regional and older stress field induced by the indentation and rotation of the Apulia-Adria plate. The kinematics of Apulia-Adria may well have played a fundamental role more regionally in determining the late stage brittle deformation at the junction between the Western Alps and the Northern Apennine (Molli et al., 2010). Other major geodynamic events such as the opening of the LiguroProvencal basin and the northern Apennines arc development are also related to the final bending and tightening of the Western Alps arc (Schmid et al. 2016). We suggest integrating all those geodynamic components into a detailed analysis of the regional stress field evolution during the Neogene in order to better understand the complexity of the area.

\section{- CONCLUSIONS}

Structural analysis of late brittle faulting together with palaeostress determinations from inversion of fault/striae kinematics reveal a complex pattern of deformation in the internal south-Western Alps, behind the 
Argentera massif, involving extensional and strike-slip deformations. The extension previously described in the internal zones at the east of the Pelvoux massif is confirmed further south but is there strongly combined with westward increasing influence of strike-slip deformation. We propose that those two regimes of deformation are contemporaneous and highlight interferences between extension parallel to the strike of the belt and probably related to the indentation itself, and strike-slip strain field essentially driven by the counterclockwise rotation of the ApuliaAdria plate. We point out the importance of the curved geometry of the belt as the main factor that constrains the direction of extension and the coupling relationship between the internal and external zones. The South-Western Alps have a unique tectonic architecture and location with respect to rotation of the Apulia-Adria plate which leads to the deformation history documented in this work. They represent a transitional zone between extension in the inner chain and strike-slip/contraction in the outer parts.

\section{- ACKNOWLEDGEMENTS}

This work was supported by The ISTerre laboratory (Grenoble Alpes University and CNRS) in Grenoble. We thank Jean Huet for his remarkable aerial photographs from his website http://www.jean-huet.com/home.html and book 'A tire d'ailes' (Huet, 2009). We wish to thank Marjorie Dennequin for her helpful assistance during fieldwork. The authors also gratefully acknowledge the reviews of G. Molli and M. Vrabec.

\section{- REFERENCES CITED}

Agard P (2001) Tectonometamorphic evolution of the Schistes Lustres Complex; implications for the exhumation of HP and UHP rocks in the Western Alps. Bulletin de La Société Géologique de France, 172:617-636, doi: $10.2113 / 172.5 .617$.

Agard P, Monie P, Jolivet L, Goffe B (2002) Exhumation of the Schistes Lustres complex: in situ laser probe Ar40/Ar-39 constraints and implications for the Western Alps. Journal of Metamorphic Geology 20:599-618.

Allanic C (2012) Kinematics, Age and Dynamic of the Brittle Deformation within the Lepontine Dome (Central Alps). Ph.D. Dissertation, University of Orléans.

Anderson EM (1951) The dynamic of faulting and dyke formation with applications to Britain 2nd ed. Edinburgh. 
Oliver \& Boyd.

Angelier J (1984) Tectonic analysis of fault slip data sets. Journal of Geophysical Research 89:5835-5848.

Angelier J (1990) Inversion of field data in fault tectonics to obtain the regional stress - A new rapid direct inversion method by analytical means. Geophysical Journal International 103:363-376.

Angelier J, Mechler P (1977) Sur une méthode graphique de recherche des contraintes principales également utilisable en tectonique et en sismologie : la méthode des dihèdres droits. Bulletin De La Societe Geologique De France, 7:1309-1318.

Baietto A, Perello P, Cadoppi P, Martinotti G (2009) Alpine tectonic evolution and thermal water circulations of the Argentera Massif (South-Western Alps): Swiss Journal of Geosciences, 102:223-245. doi:10.1007/s00015009-1313-5.

Baran R, Friedrich AM, Schlunegger F (2014) The late Miocene to Holocene erosion pattern of the Alpine foreland basin reflects Eurasian slab unloading beneath the western Alps rather than global climate change.

Lithosphere 6:124-31. doi:10.1130/L307.1

Barbieri C, Carrapa B, Di Giulio A, Wijbrans J, Murrell GR (2003) Provenance of Oligocene synorogenic sediments of the Ligurian Alps (NW Italy): inferences on belt age and cooling history. International Journal of Earth Sciences 92:758-778.

Baroux E, Béthoux N, Bellier O (2001) Analyses of the stress field in southeastern France from earthquake focal mechanisms: Geophysical Journal International 145:336-348. doi:10.1046/j.1365-246X.2001.01362.x

Barruol G, Deschamps A, Coutant O. (2004) Mapping upper mantle anisotropy beneath SE France by SKS splitting indicates Neogene asthenospheric flow induced by Apenninic slab roll-back and deflected by the deep Alpine roots. Tectonophysics, Elsevier, 394 (1-2):125-138. doi:10.1016/j.tecto.2004.08.002.

Bauve V, Plateaux R, Rolland Y, Sanchez G, Bethoux N, Delouis B, Darnault R (2014) Long-lasting transcurrent tectonics in SW Alps evidenced by Neogene to present-day stress fields. Tectonophysics 621:85-100. doi: $\underline{10.1016 / \text { j.tecto.2014.02.006 }}$

Bauve V, Rolland Y, Sanchez G, Giannerini G, Schreiber D, Corsini M, Perez JL, Romagny A (2012) Pliocene to Quaternary deformation in the Var Basin (Nice, SE France) and its interpretation in terms of 'slow-active' faulting. Swiss Journal of Geosciences 105:361-76. doi:10.1007/s00015-012-0106-4

Bellahsen N, Jolivet L, Lacombe O, Bellanger M, Boutoux A, Garcia S, Mouthereau F, Le Pourhiet L, Gumiaux C 
(2012) Mechanisms of margin inversion in the external Western Alps: Implications for crustal rheology. Tectonophysics 560-561:62-83. doi:10.1016/j.tecto.2012.06.022

Bertrand A, Rosenberg C, Garcia S (2015) Fault slip analysis and late exhumation of the Tauern Window, Eastern Alps. Tectonophysics 649:1-17. doi:10.1016/j.tecto.2015.01.002

Bertrand A, Sue C (2017) Reconciling late faulting over the whole Alpine belt: from structural analysis to geochronological constrains. Swiss Journal of Geosciences. http://doi.org/10.1007/s00015-017-0265-4

Beucher R. (2009) Evolution Néogène de l'arc alpin sud-occidental : Approches sismotectonique et thermochronologique. Géologie appliquée. Ph. D thesis, Université Joseph-Fourier - Grenoble I

Bigot-Cormier F, Sosson M, Poupeau G, Stéphan JF., and Labrin E (2006) The denudation history of the Argentera Alpine External Crystalline Massif (Western Alps, France-Italy): an overview from the analysis of fission tracks in apatites and zircons. Geodinamica Acta 19:455-473. doi:10.3166/ga.19.455-473

Bistacchi A, Massironi M (2000) Post-nappe brittle tectonics and kinematic evolution of the north-western Alps: an integrated approach. Tectonophysics 327:267-292. doi:10.1016/S0040-1951 (00)00206-7

Bogdanoff S, Michard A, Mansour M, Poupeau G (2000) Apatite fission track analysis in the Argentera massif: Evidence of contrasting denudation rates in the external crystalline massifs of the Western Alps. Terra Nova 12:117-125. doi:10.1111/j.1365-3121.2000.00281.x

Bott MHP (1959) The Mechanics of Oblique Slip Faulting. Geological Magazine 96:109-117. doi:10.1017/S0016756800059987

Bousquet R, Oberhansli R, Goffe B, Wiederkehr M, Koller F, Schmid SM, Schuster R, Engi M, Berger A, and Martinotti G (2008) Metamorphism of metasediments at the scale of an orogen: a key to the Tertiary geodynamic evolution of the Alps. In: Fügenschuh S, Siegesmund B, Froitzheim N (eds) Geological Society of London Special Publications 298:393-411. doi: $\underline{10.1144 / \text { SP298.18 }}$

Bucher S, (2003) The Briançonnais units along the ECORS-CROP transect (Italian-French Alps): structures, metamorphism and geochronology. Ph. D Thesis. Universität Basel

Calais E, Nocquet JMM, Jouanne F, Tardy M (2002) Current strain regime in the Western Alps from continuous Global Positioning System measurements, 1996-2001. Geology 30:651-654. doi:10.1130/0091-7613 (2002)030<0651:CSRITW>2.0.CO; 2

Carrapa B, Wijbrans J, Bertotti G (2003) Episodic exhumation in the Western Alps. Geology 31:601-604. 
Champagnac JD, Sue C, Delacou B, Burkhard M (2003) Brittle orogen-parallel extension in the internal zones of the Swiss Alps (South Valais). Eclogae Geologicae Helvetiae 96:325-326

Champagnac JD, Sue C, Delacou B, Tricart P, Allanic C, Burkhard M (2006) Miocene lateral extrusion in the inner western Alps revealed by dynamic fault analysis. Tectonics 25. doi:10.1029/2004TC001779

Champagnac JD, Molnar P, Anderson RS, Sue C, Delacou B (2007) Quaternary erosion-induced isostatic rebound in the western Alps. Geology 35:195. doi:10.1130/G23053A.1

Champagnac JD, Sue C, Delacou B, Burkhard M, (2004) Brittle deformation in the inner NW Alps: from early orogen-parallel extrusion to late orogen-perpendicular collapse. Terra Nova 16:232-242. doi:10.1111/j.1365$\underline{3121.2004 .00555 . \mathrm{x}}$

Chéry J, Genti M, Vernant P (2016) Ice cap melting and low-viscosity crustal root explain the narrow geodetic uplift of the Western Alps. Geophysical Research Letters 43:3193-3200. doi:10.1002/2016GL067821

Ciancaleoni L, Marquer D (2008) Late Oligocene to early Miocene lateral extrusion at the eastern border of the Lepontine dome of the central Alps (Bergell and Insubric areas, eastern central Alps). Tectonics 27. doi: $10.1029 / 2007$ TC002196

Collombet M, Thomas JC, Chauvin A, Tricart P, Bouillin JP, and Gratier JP (2002) Counterclockwise rotation of the western Alps since the Oligocene: New insights from paleomagnetic data. Tectonics 21:14-11-14-15. doi: $\underline{10.1029 / 2001 T C 901016}$

Corsini M, Ruffet G, Caby R (2004) Alpine and late-hercynian geochronological constraints in the Argentera Massif (Western Alps). Eclogae Geologicae Helvetiae 97:3-15. doi:10.1007/s00015-004-1107-8

Courboulex F, Larroque C, Deschamps A, Gélis C, Charreau J, Stéphan JF (2003) An unknown active fault revealed by microseismicity in the south-east of France. Geophys. Res. Lett. 30:1782.

D’Atri A, Piana F, Barale L, Bertok C, Martire L (2016) Geological setting of the southern termination of Western Alps. Int J Earth Sci (Geol Rundsch) 105: 1831. doi:10.1007/s00531-015-1277-9

Debelmas, J (1986) The Western Alpine Arc: new data and hypothesis. In: Wezel, F.C. (ed) The Origins of Arcs, Elsevier, 233-251.

Delacou B, Sue C, Champagnac JD, Burkhard M (2004) Present-day geodynamics in the bend of the western and central Alps as constrained by earthquake analysis. Geophysical Journal International 158:753-774.

Duchêne S, Blichert-Toft J, Luais B, Télouk P, Lardeaux JM, Albarède F (1997) The Lu-Hf dating of garnets and 
the ages of the Alpine high-pressure metamorphism. Nature 387:586-589

Dumont T, Schwartz S, Guillot S, Simon-Labric T, Tricart P, Jourdan S (2012) Structural and sedimentary records of the Oligocene revolution in the Western Alpine arc. Journal of Geodynamics 56-57:18-38, doi:10.1016/j.jog.2011.11.006

Etchecopar A, Vasseur G, and Daignieres M (1981) An inverse problem in microtectonics for the determination of stress tensors from fault striation analysis. Journal of Structural Geology 3:51-65. doi: $10.1016 / 0191-8141$ $\underline{(81) 90056-0}$

Eva E, Pastore S, Deichmann N (1998) Evidence for ongoing extensional deformation in the western Swiss Alps and thrust-faulting in the southwestern Alpine foreland. Journal Of Geodynamics 26:27-43.

Ford M, Duchene S, Gasquet D, Vanderhaeghe O (2006) Two-phase orogenic convergence in the external and internal SW Alps. Journal of the Geological Society 163:815-826. doi:10.1144/0016-76492005-034

Fox M, Herman F, Kissling E, Willett SD (2015) Rapid exhumation in the Western Alps driven by slab detachment and glacial erosion. Geology 43:379-382. doi:10.1130/G36411.1

Frey M, Desmon J, Neubauer F (1999) Metamorphic maps of the Alps: Schweiz. Mineral. Petrogr. Mitt. 79:1-4.

Frohlich C (1992) Triangle diagrams: ternary graphs to display similarity and diversity of earthquake focal mechanisms. Physics of the Earth and Planetary Interiors 75:193-198. doi:10.1016/0031-9201 (92)90130-N

Giannerini G, Sanchez G, Schreiber D, Lardeaux JM, Rolland Y, de Castro AB., Bauve V (2011) Geometry and sedimentary evolution of the transpresssive Roquebrune-Cap Martin basin: implications on the kinematics and timing of the Nice arc deformation during Miocene times, SW Alps. Bulletin de La Societe Geologique de France 182:493-506. doi:10.2113/gssgfbull.182.6.493

Gidon M (1974) Alpine arc with vortical origin : Comptes Rendus Hebdomadaires Des Séances de L'académie Des Sciences, ser. D. 27:21.

Gidon M (2000) Les chaînons subalpins au nord-est de Sisteron et l'histoire tectonique de la nappe de Digne, The subalpine ranges at the NE of Sisteron and the tectonic history of the Digne thrust. Geologie Alpine 73:23-57.

Gigot P, Grandjacquet C, Haccard D (1974) Evolution tectono-sedimentaire de la bordure septentrionale du bassin tertiaire de Digne depuis l’Eocene. Bulletin de La Société Géologique de France, ser. 7. 16:128-139. doi:10.2113/gssgfbull.S7-XVI.2.128

Gnaccolini M, Gelati R, Falletti P, Catrullo D (1998) Sequence stratigraphy of the "Langhe" Oligo-Miocene 
succession, Tertiary Piedmont Basin, northern Italy. In: Mesozoic and Cenozoic sequence stratigraphy of European basins, pp. 234-244, ed. Graciansky, P. C., et al. SEPM (Society for Sedimentary Geology) Special Publication.

Goguel, J (1963) L'interprétation de l'arc des Alpes occidentals. Bulletin Societé Géologique France 7(5) : 20-33. Graciansky PC, Roberts D, Tricart P (2010) The Western Alps, from Rift to Passive Margin to Orogenic Belt: An Integrated Geoscience Overview. In Shroder JF (ed.) Elsevier, 432p.

Grosjean G, Sue C, Burkhard M (2004) Late Neogene extension in the vicinity of the Simplon fault zone (central Alps, Switzerland). Eclogae Geologicae Helvetiae 97:33-46. doi:10.1007/s00015-004-1114-9

Handy MR, Schmid SM, Bousquet R, Kissling E, Bernoulli D (2010) Reconciling plate-tectonic reconstructions of Alpine Tethys with the geological - geophysical record of spreading and subduction in the Alps. Earth-Science Reviews 102:121-158. doi:10.1016/j.earscirev.2010.06.002

Hippolyte JC, Dumont T (2000) Identification of Quaternary thrusts, folds and faults in a low seismicity area: examples in the Southern Alps (France). Terra Nova 12:156-62. doi:10.1046/j.1365-3121.2000.00287.x Huet J (2009) Alpes de Haute-Provence, à tire d'ailes. Jean Huet, http://www.jean-huet.com/home.html. Jenatton L, Guiguet R, Thouvenot F, Daix N (2007) The 16,000-event 2003-2004 earthquake swarm in Ubaye (French Alps). Journal of Geophysical Research 112:B11304, doi:10.1029/2006JB004878

Kurz W, Neubauer F, Genser J, Horner H (1993) Sequence of Tertiary Brittle Deformations in the Eastern Tauern Window (Eastern Alps). Mitt. Österr. Geol. 86:153-164.

Labaume P, Ritz JF, Philip H (1989) Recent normal faults in the southwestern Alps: their relationships with the compression tectonics. Comptes Rendus de L’Académie Des Sciences (Paris) ser. 2308 : 1553-1560.

Lacombe O (2012) Do fault slip data inversions actually yield 'paleostresses' that can be compared with contemporary stresses? A critical discussion. Comptes Rendus - Geoscience 344:159-173. doi: $\underline{10.1016 / j . c r t e .2012 .01 .006}$

Lambert J, Levret-Albaret A (1996) Mille ans de Séismes en France, Catalogue D’épicentres. Paramètres et Références. Ouest Éditions, Nantes.

Lanari P, Guillot S, Schwartz S, Vidal O, Tricart P, Riel N, Beyssac O (2012) Diachronous evolution of the alpine continental subduction wedge: Evidence from $\mathrm{P}-\mathrm{T}$ estimates in the Briançonnais Zone houillère (France Western Alps). Journal of Geodynamics 56-57:39-54. doi:10.1016/j.jog.2011.09.006 
Lanari P, Rolland Y, Schwartz S, Vidal O, Guillot S, Tricart P, Dumont T (2014) P - T - t estimation of deformation in low-grade quartz-feldspar-bearing rocks using thermodynamic modelling and 40Ar/39Ar dating techniques: example of the Plan-de-Phasy shear zone unit (Briançonnais Zone, Western Alps). Terra Nova 26:130-138. doi: $10.1111 /$ ter. 12079

Lardeaux JM, Schwartz S, Tricart P, Paul A, Guillot S, Béthoux N, Masson F (2006) A crustal-scale cross-section of the south-western Alps combining geophysical and geological and geological imagery. Terra Nova 18:412-422

Larroque C, Delouis B, Godel B, Nocquet, JM (2009) Active deformation at the southwestern Alps-Ligurian basin junction (France-Italy boundary): Evidence for recent change from compression to extension in the Argentera massif. Tectonophysics 467:22-34.

Laubscher H (1996) Shallow and deep rotations in the Miocene Alps. Tectonics 15:1022-1035. doi:10.1029/96TC00432

Laurent O, Stephan JF, Popoff M (2000) Modalités de la structuration miocène de la branche sud de l'arc de Castellane (chaîne subalpines méridionales). Géologie de La France 3:33-65.

Maffione M, Speranza F, Faccenna C, Cascella A, Vignaroli G, Sagnotti L (2008) A synchronous Alpine and Corsica-Sardinia rotation. Journal of Geophysical Research 113:B03104, doi:10.1029/2007JB005214

Malusà MG, Polino R, Zattin M (2009) Strain partitioning in the axial NW Alps since the Oligocene. Tectonics 28:3 Ménard G (1988) Structure et cinématique d’une chaîne de collision : les Alpes ocidentales et centrales. Ph.D. thesis. Grenoble, Université Joseph-Fourier.

Ménard G (1979) Relations entre structures profondes et structures superficielles dans le sud-est de la France. Essai d'utilisation de données géophysiques, Thesis, Universite Scientifique et Medicale de Grenoble.

Mohn G, Manatschal G, Muntener O, Beltrando M, Masini E (2010) Unravelling the interaction between tectonic and sedimentary processes during lithospheric thinning in the Alpine Tethys margins. International Journal of Earth Sciences 99:75-101. doi:10.1007/s00531-010-0566-6

Molli G, Crispini L, Malusa M, Mosca P, Piana P, Federico L (2010) Geology of the Western Alps-Northern Apennine junction area: a regional review. Journal of the Virtual Explorer 36, paper 10 of the electronic edition ISSN 1441-8142.

Nocquet JM, Sue C, Walpersdorf A, Tran T, Lenôtre N, Vernant P, Cushing M, et al. (2016) Present-day uplift of the western Alps. Nature Sci. Report, (in press). 
Ortner H, Reitera F, Acs P (2002) Easy handling of tectonic data: the programs TectonicVB for Mac and TectonicsFP for Windows ${ }^{\mathrm{TM}}$. Computers \& Geosciences 28:1193-1200. doi:10.1016/S0098-3004 (02)00038-9

Perrone G, Cadoppi P, Tallone S, Balestro G (2011) Post-collisional tectonics in the Northern Cottian Alps (Italian Western Alps). International Journal of Earth Sciences 100:1349-1373. doi: $10.1007 / \mathrm{s} 00531-010-0534-1$

Qorbani E, Bianchi I, Bokelmann G (2015) Slab detachment under the Eastern Alps seen by seismic anisotropy.

Earth and Planetary Science Letters 409:96-108. doi : 10.1016/j.epsl.2014.10.049

Ritz JF (1992) Tectonique récente et sismotectonique des Alpes du sud : analyse en termes de contraintes. Quaternaire 3:111-124.

Rubatto D, Hermann J (2003) Zircon formation during fluid circulation in eclogites (Monviso, Western Alps): Implications for Zr and Hf budget in subduction zones. Geochimica Et Cosmochimica Acta 67:2173-2187. Sanchez G, Rolland Y, Jolivet M, Brichau S, Corsini M, Carter A (2011) Exhumation controlled by transcurrent tectonics: The Argentera-Mercantour massif (SW Alps). Terra Nova 23:116-126. doi:10.1111/j.13653121.2011.00991.x

Sanchez G, Rolland Y, Schneider J, Corsini M, Oliot E, Goncalves P, Verati C, Lardeaux JM, Marquer D (2011) Dating low-temperature deformation by 40Ar/39Ar on white mica, insights from the Argentera-Mercantour Massif (SW Alps). Lithos 125:521-536. doi:10.1016/j.lithos.2011.03.009

Sanchez G, Rolland Y, Schreiber D, Giannerini G, Corsini M, Lardeaux JM (2010) The active fault system of SW Alps. Journal of Geodynamics 49:296-302. doi:10.1016/j.jog.2009.11.009

Schmid S, Kissling E, Diehl T, vanHinsbergen DJJ, Molli G (2016) Ivrea mantle wedge, arc of the Western Alps, and kinematic evolution of the Alps-Apennines orogenic system. Swiss Journal of Earth Sciences: in press.

Sébrier M, Ghafiri A, Bles JL (1997) Paleoseismicity in France: fault trench studies in a region of moderate seismicity. J. Geodyn. 24:207-217.

Schlunegger F, Kissling E (2015) Slab rollback orogeny in the Alps and evolution of the Swiss Molasse basin. Nature Communications 6:8605. doi: $10.1038 /$ ncomms9605

Schmid SM, Kissling E (2000) The arc of the western Alps in the light of geophysical data on deep crustal structure. Tectonics 19:62-85. doi:10.1029/1999TC900057

Schreiber D, Lardeaux JM, Martelet G, Courrioux G, Guillen A (2010) 3D modelling of Alpine Mohos in Southwestern Alps. Geophys. J. Int. 180:961-975. 
Schreiber D, Giannerini D, Lardeaux JM (2011) The Southeast France basin during Late Cretaceous times: The spatiotemporal link between Pyrenean collision and Alpine subduction. Geodinamica Acta 24:21-35. doi:10.3166/ga.24.21-35

Schwartz S, Lardeaux JM, Guillot S, Tricart P (2000) The diversity of eclogitic metamorphism in the Monviso ophiolitic complex, western Alps, Italy. Geodinamica Acta 13:169-188.

Schwartz S, Lardeaux JM, Tricart P, Guillot S, Labrin E (2007) Diachronous exhumation of HP-LT metamorphic rocks from south-western Alps: evidence from fission-track analysis. Terra Nova 19:133-140.

Seeber L, Pêcher A (1998) Strain partitioning along the Himalayan arc and the Nanga Parbat antiform. Geology 26:791. doi:10.1130/0091-7613 (1998)026<0791:SPATHA>2.3.CO; 2

Selverstone J (2005) Are the Alps Collapsing? Annual Review of Earth and Planetary Sciences 33:113-132. doi:10.1146/annurev.earth.33.092203.122535

Serpelloni E, Faccenna C, Giorgio S, Dong D, Williams SDP (2013) Vertical GPS ground motion rates in the EuroMediterranean region: New evidence of velocity gradients at different spatial scales along the Nubia-Eurasia plate boundary. Journal of Geophysical Research: Solid Earth 118:6003-6024. doi:10.1002/2013JB010102

Seward D, Mancktelow NS (1994) Neogene kinematics of the central and western alps - evidence from fission-track dating. Geology 22:803-806.

Simon-labric T, Rolland Y, Dumont T, Heymes T, Authemayou C, Corsini M, Fornari M (2009) 40Ar/39Ar dating of Penninic Front tectonic displacement (W Alps) during the Lower Oligocene (31-34Ma). Terra

Nova 21:127-136. doi:10.1111/j.1365-3121.2009.00865.x

Spang JH (1972) Numerical Method for Dynamic Analysis of Calcite Twin Lamellae. Geological Society Of America Bulletin 83:467-472.

Sturani C (1962) Il complesso sedimentario autoctono all' estremo nord-occidentale del Massicio dell' Argentera (Alpi Marittime). Ph.D. thesis. Torino, Univ. Padova.

Sue C, Tricart P (1999) Late Alpine brittle extension above the Frontal Pennine Thrust near Briancon, Western Alps. Eclogae Geologicae Helvetiae 92:171-181.

Sue C (1998) Dynamique actuelle et récente des Alpes occidentales internes : Approches structurale et sismologique. Ph.D. thesis. Grenoble, Université Joseph Fourier.

Sue C, Tricart P (2002) Widespread post-nappe normal faulting in the Internal Western Alps: a new constraint on 
arc dynamics. Journal of the Geological Society 159:61-70. doi:10.1144/0016-764901-026

Sue C, Tricart P (2003a) Late Alpine brittle extension above the Frontal Pennine Thrust near Briançon, Western Alps. Eclogae Geologicae Helvetiae 96:325-338.

Sue C, Tricart P (2003b) Neogene to ongoing normal faulting in the inner western Alps: A major evolution of the alpine tectonics. Tectonics 22:1-25.

Sue C, Delacou B, Champagnac JD, Allanic C, Tricart P, Burkhard M (2007) Extensional neotectonics around the bend of the Western/Central Alps: An overview. International Journal of Earth Sciences 96:1101-1129. doi: $10.1007 / \mathrm{s} 00531-007-0181-3$

Sue C, Calcagno P, Courrioux G, Tricart P, Fréchet J, Thouvenot F (2010) Relationshipsbetween inherited crustal structures and seismicity in the western Alps inferred from 3D structural modeling. Bull. Soc. Geol. Fr. 181:583-590.

Sue C, Thouvenot F, Fréchet J, Tricart P (1999) Widespread extension in the core of the western Alps revealed by earthquake analysis. Journal of Geophysical Research v. 104:25611-25622. doi:10.1029/1999JB900249

Tapponnier P (1977) Evolution tectonique du systeme alpin en Mediterranee; poinconnement et ecrasement rigideplastique. Bulletin de La Société Géologique de France 19:437-460. doi:10.2113/gssgfbull.S7-XIX.3.437

Tricart P (1984) From passive margin to continental collision: A tectonic scenario for the western Alps. American Journal Of Science 284:97-120.

Tricart P (2004) From extension to transpression during the final exhumation of the Pelvoux and Argentera massifs, Western Alps. Eclogae Geologicae Helvetiae 97:429-439. doi: 10.1007/s00015-004-1138-1

Tricart P, Lardeaux JM, Schwartz S, Sue C (2006) The late extension in the inner western Alps: a synthesis along the south-Pelvoux transect. Bulletin De La Societe Geologique De France 177:299-310.

Tricart P, van der Beek PV, Schwartz S, Labrin E (2007) Diachronous late-stage exhumation across the western Alpine arc: constraints from apatite fission-track thermochronology between the Pelvoux and Dora-Maira Massifs. Journal of the Geological Society of London 164:163-174.

Turner FJ (1953) Nature and dynamic interpretation of deformation lamellae in calcite of three marbles. American Journal Of Science 251:276-298.

Vance JA (1999) Zircon fission track evidence for a Jurassic (Tethyan) thermal event in the Western Alps. Memorie di Scienze Geologiche, Padova 51:473-476. 
Vernant P, Hivert F, Chéry J, Steer P, Cattin R, Rigo A (2013) Erosion-induced isostatic rebound triggers extension in low convergent mountain ranges. Geology 41:467-470. doi:10.1130/G33942.1

Vialon P, Rochette P, Menard G (1989) Indentation and rotation in the western Alpine arc. In. Dietrich D, Coward MP, Park RG (eds), Geological Society of London Special Publications 45:329-338. doi:10.1144/GSL.SP.1989.045.01.18

Wallace RE (1951) Geometry of shearing stress and relation to faulting. Journal of Geology 59:118-130.

Wang X, Neubauer F (1998) Orogen-parallel strike-slip faults bordering metamorphic core complexes: the SalzachEnns fault zone in the eastern Alps, Austria. Journal of Structural Geology 20:799-818. doi:10.1016/S0191$\underline{8141(98) 00013-3}$

Yamaji A (2000) The multiple inverse method: A new technique to separate stresses from heterogeneous fault-slip data. Journal of Structural Geology 22:441-452. doi:10.1016/S0191-8141 (99)00163-7

Yamaji A (2002) Are the solutions of stress inversion correct? Visualization of their reliability and the separation of stresses from heterogeneous fault-slip data. Journal of Structural Geology 25:241-252. doi:10.1016/S0191$\underline{8141(02) 00021-4}$

Zhao L, Paul A, Guillot S, Solarino S, Malusa MG, Zheng T, Aubert C, Salimbeni S, Dumont T, Shwartz S, Zhu R, Wang Q (2015) First seismic evidence for continental subduction beneath the Western Alps: Geology 43:815819. doi: $\underline{10.1130 / \mathrm{G} 36833.1}$

Zwingmann H, Mancktelow N (2004) Timing of Alpine fault gouges. Earth and Planetary Science Letters 223:415425, doi:10.1016/j.eps1.2004.04.041

\section{FIGURES CAPTIONS}

Figure 1. Simplified tectonic map of the Western Alps outlying the Neogene kinematics. AA - Aar; MB - Mont Blanc; BL - Belledonne; Px - Pelvoux; AR - Argentera; SFZ - Simplon Fault Zone ; CPF - Crustal Penninic Front. Adapted from (Collombet et al., 2002; Champagnac et al., 2007)

Figure 2. Simplified geological map of the studied area with the main Alpine tectonic zones and the main supposedactive faults (after Sanchez et al., 2010). CPF: Crustal Penninic Front (Sue and Tricart, 2003b); PFT: Penninic 
Frontal Thrust; Jz: Jausiers fault; SF: Serenne fault; Bz: Bersézio. Red bold letters A to D refer to locations of photographs presented in Figure 4. The yellow and orange stars locate the structural examples presented in Figure 5 and 6 respectively.

Figure 3. Map showing the lineaments identified from analysis of shaded Shuttle Radar Topography Mission Digital Elevation Model (red lines) and aerial photographs from the Institut Géographique National, France (blue lines with area zoomed as insert). The lineaments are interpreted to be faults based on morphotectonic evidences. The green dots locate the measurement sites used to compute the palaeostress tensors analysed in this study. The rose-diagrams illustrate the statistical lineaments directions. CPF: Crustal Penninic Front (Sue and Tricart, 2003b); Bz: Bersézio fault.

Figure 4. Morphological expression of faulting systems: A, B: Examples of brittle strike-slip structures observed along the NW-SE lineaments parallel to the Bersezio fault (from (Huet, 2009) with permission); C, D: Examples of brittle extensional structures trending N-S or N. See Figure 2 for locations.

Figure 5. Mount Arpet site showing an example of two-stages of faulting; extensional deformation followed by strike-slip deformation (See Figure 2 for location). Top: conjugate normal faults indicate extensional movements related to an early tectonic stage. Fault/striae pairs measurements along the outcrop lead to an extensional tensor solution, shown with the histogram of misfits. Bottom: Near-horizontal slickenlines highlight a second tectonic stage with dominant strike-slip deformation. A second tensor is calculated, which shows a N-S compression axis.

Figure 6. 'Fouillouse'/‘Col sans nom' site showing a three-stage evolution along a NW-SE fault (See Figure 2 for location). (A) General view of the NW-SE trending fault surface with metre-scale tectonic grooves highlighting oblique strike-slip movement. The stereogram (Wulff projection of the lower hemisphere) shows the measurements from the fault plane with striae/grooves associated to phases I (black diamonds), II (grey diamonds) and III (white diamonds). ; (B) Last tectonic movement is confirmed by drag-folds and indicates down-throw to the north-East; (C) Details illustrating a three stage evolution. Horizontal metre-scale tectonic grooves (I) are overprinted by a second generation of lower wavelength grooves (II) that moderately plunge towards the SE. Final movement (III) is 
locally testified by striae affecting the blocking flank of horizontal grooves; (C) The third movement is confirmed by drag-folds; Fault orientations and direction of slip are plotted on stereonets (Wulff projection of the lower hemisphere). Graphical estimations of the pressure $(\mathrm{P})$ and tension $(\mathrm{T})$ axes are also reported.

Figure 7. Strike and dip distributions of faults measured in the studied area. A: Rose diagram of fault strike (by classes of $10^{\circ}$ ) and B: fault dip, with the number of measured planes shown on the radius. C: cumulated percentage of fault planes as a function of dip.

Figure 8. A: Triangular 'Frohlich' diagrams (Frohlich, 1992) illustrating the tectonic regime of the paleostress tensors calculated from fault-slip data inversion. The vertices of the triangle correspond to the 'Andersonian position' with pure strike-slip (vertical $\sigma 2$ ) in green, pure compression (vertical $\sigma 3$ ) in red and pure extension (vertical $\sigma 1$ ) in blue. Angular distances from the vertices are reported every $10^{\circ}$ as thin coloured lines. In blue is the extensional zone, in red the compressional zone and in green the strike-slip zone. B: Histogram showing the frequency of paleostress tensors versus their $\varphi$ ratio (see text). The tensor database displays a wide range of $\varphi$ ratios. These tensors are separated into two categories: from $\varphi=0$ up to $\varphi=1$ for extensional tensors in blue and from $\varphi=1$ down to $\varphi=0$ for strike-slip tensors in green. Among extensional tensors, low $\varphi$ ratios prevail while $\varphi$ values are more distributed for strike-slip tensors.

Figure 9. A: Statistical distribution of $\sigma 1$ and $\sigma 3$ stress axes directions for the full tensor dataset. The grey colour indicates tensors for which $\sigma 1$ is close to the vertical (extensional regime) while the red and blue indicate the tensors for which $\sigma 2$ is close to the vertical (strike-slip regime). The diagrams show a preferential N-S orientation of the $\sigma 1$ axis while the $\sigma 3$ axis appears to be preferentially oriented E-W with some variability between $\mathrm{N} 70^{\circ}$ and $\mathrm{N} 120^{\circ}$. B: Map showing $\sigma 3$ orientations (projected sub-horizontal axis). The colours correspond to those used in figure 8 (blue is for extension and green for strike-slip). The values of the $\varphi$ ratio are indicated as coloured disks.

Figure 10. Synthetic map of the best regional $\sigma 3$ axes determined from the statistical analysis of the tensor database. CS: Briançon area between the Pelvoux, Viso and Argentera massifs [Sue and Tricart, 1999; 2002; 2003]. Due to its internal regional variability the CS dataset has been subdivided into 2 regional stereonets (CS-north and CS-south); 
VB: Stress analysis from Bauve et al., 2014; RB all: This study. The thick solid red lines indicate the directions of $\sigma 3$ for the major orogen-parallel extension signal while the thick solid blue line (CS-north) indicates the direction of $\sigma 3$ for the minor orogen-perpendicular extension signal. See text for details.

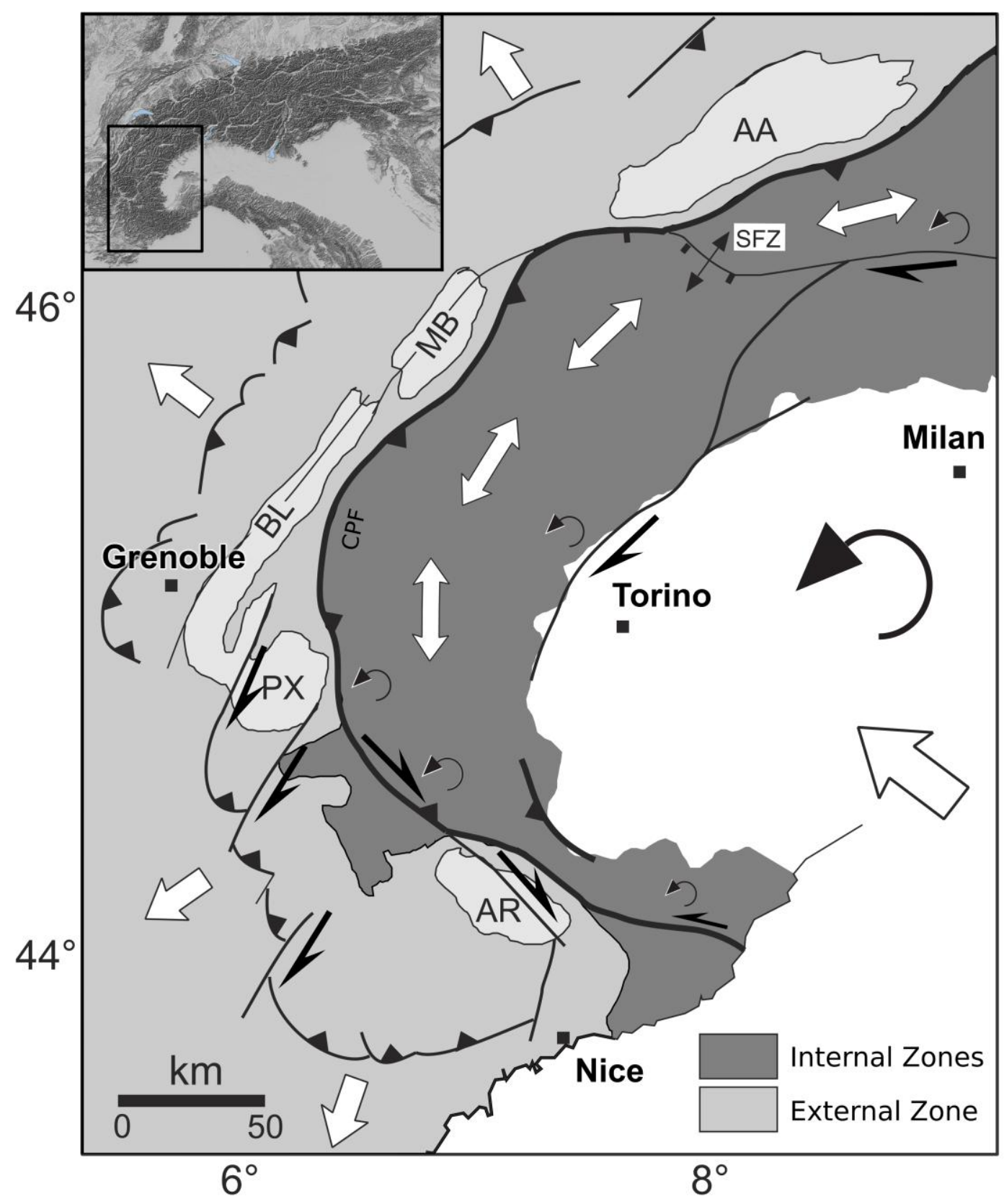




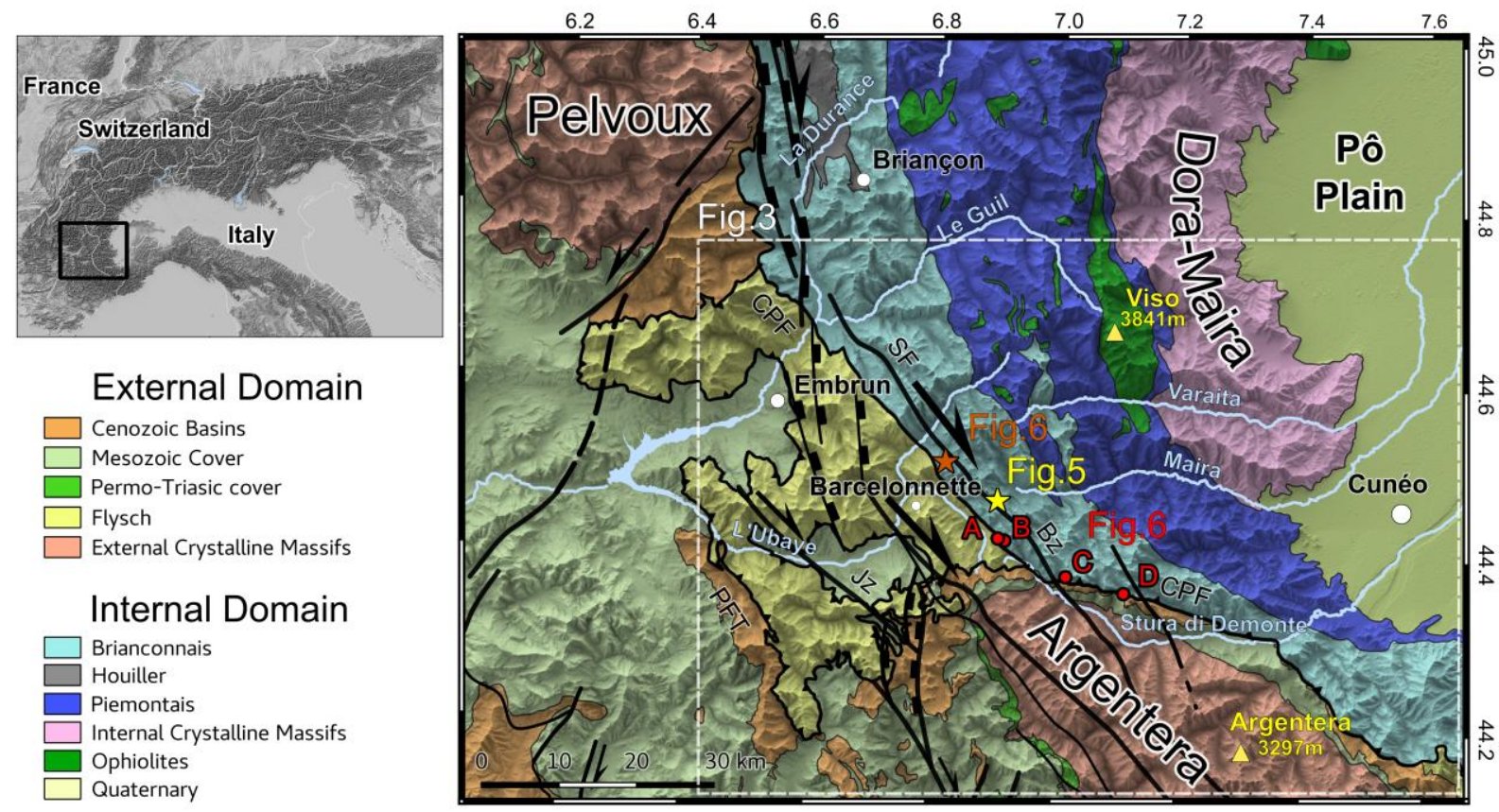



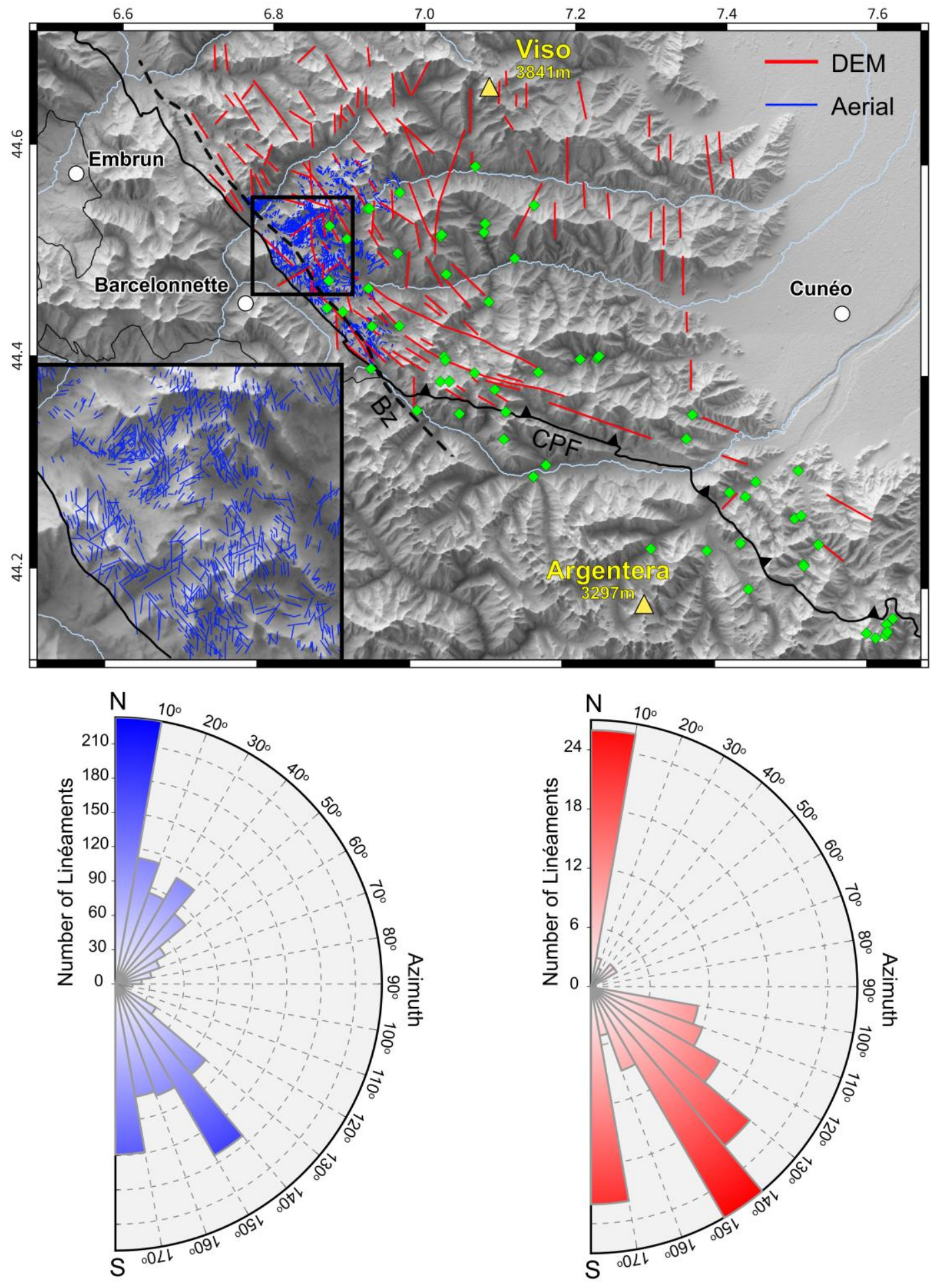

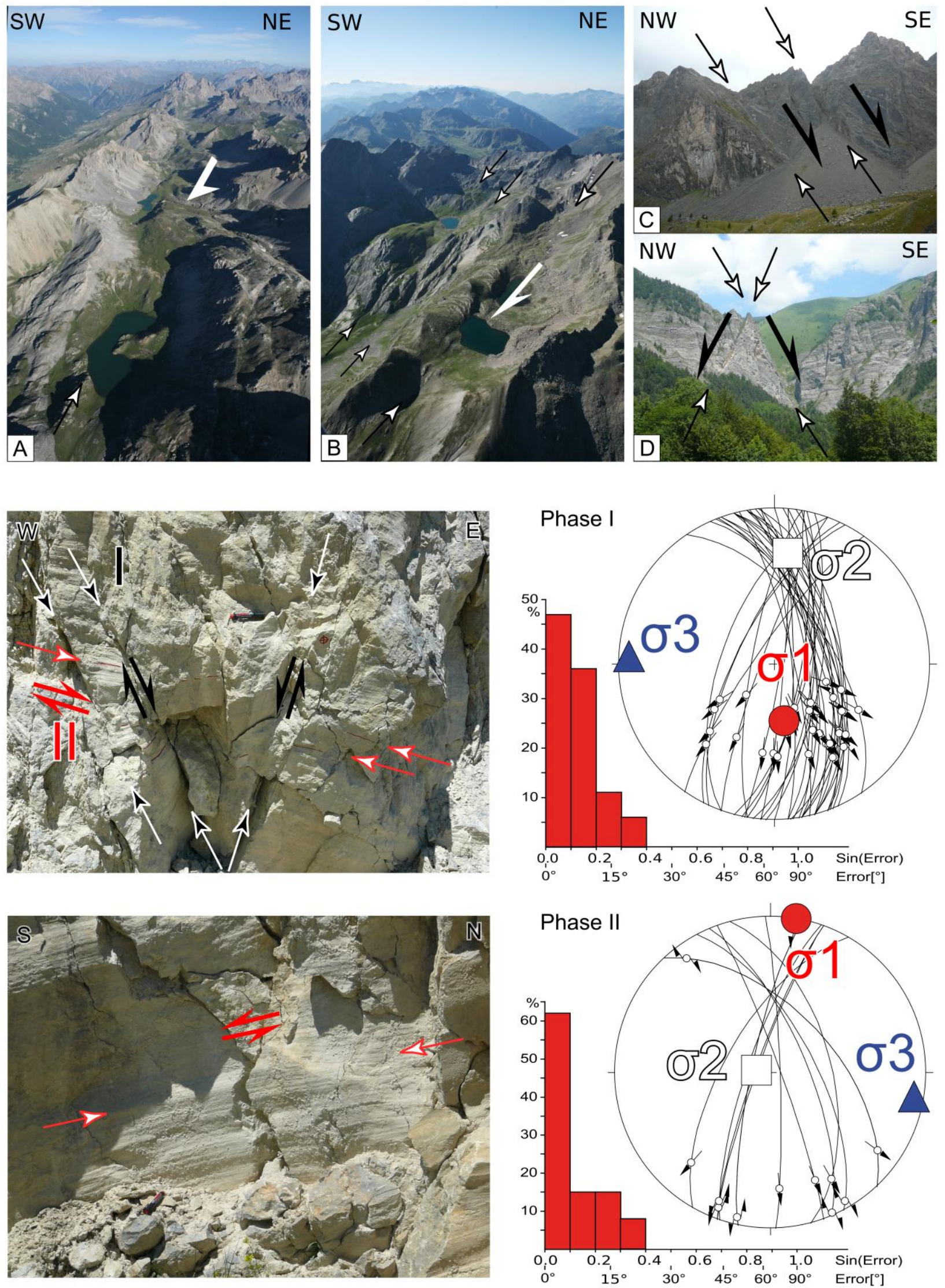

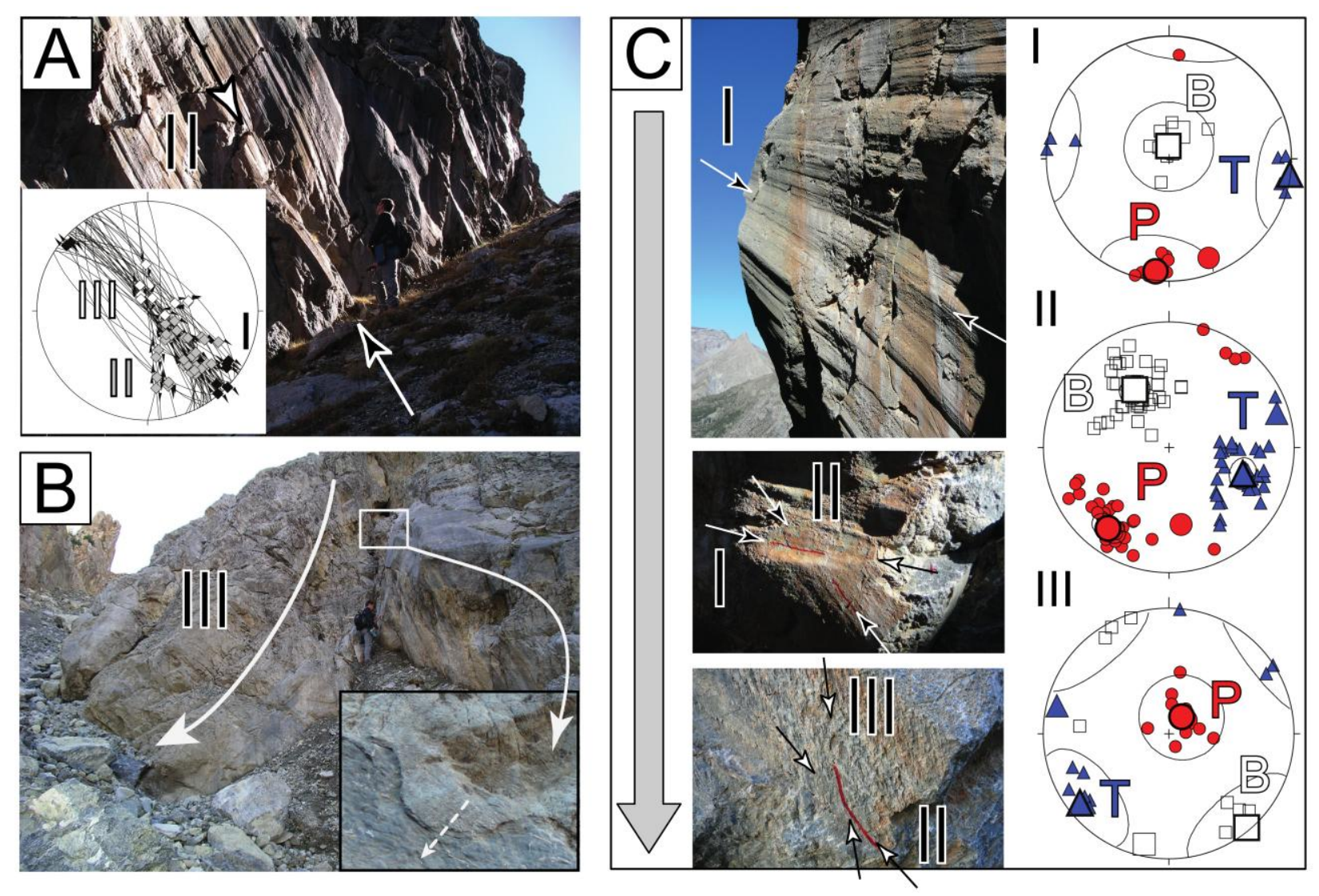
A

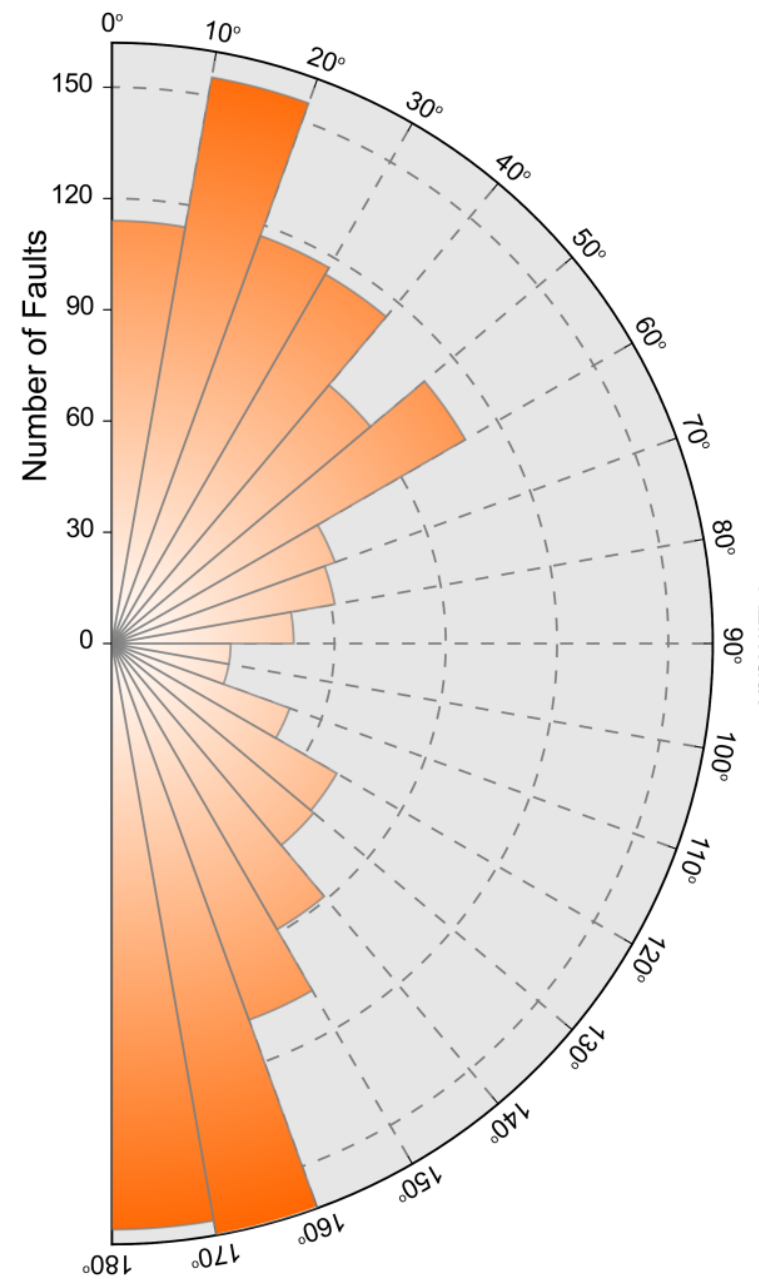

B Number of Faults

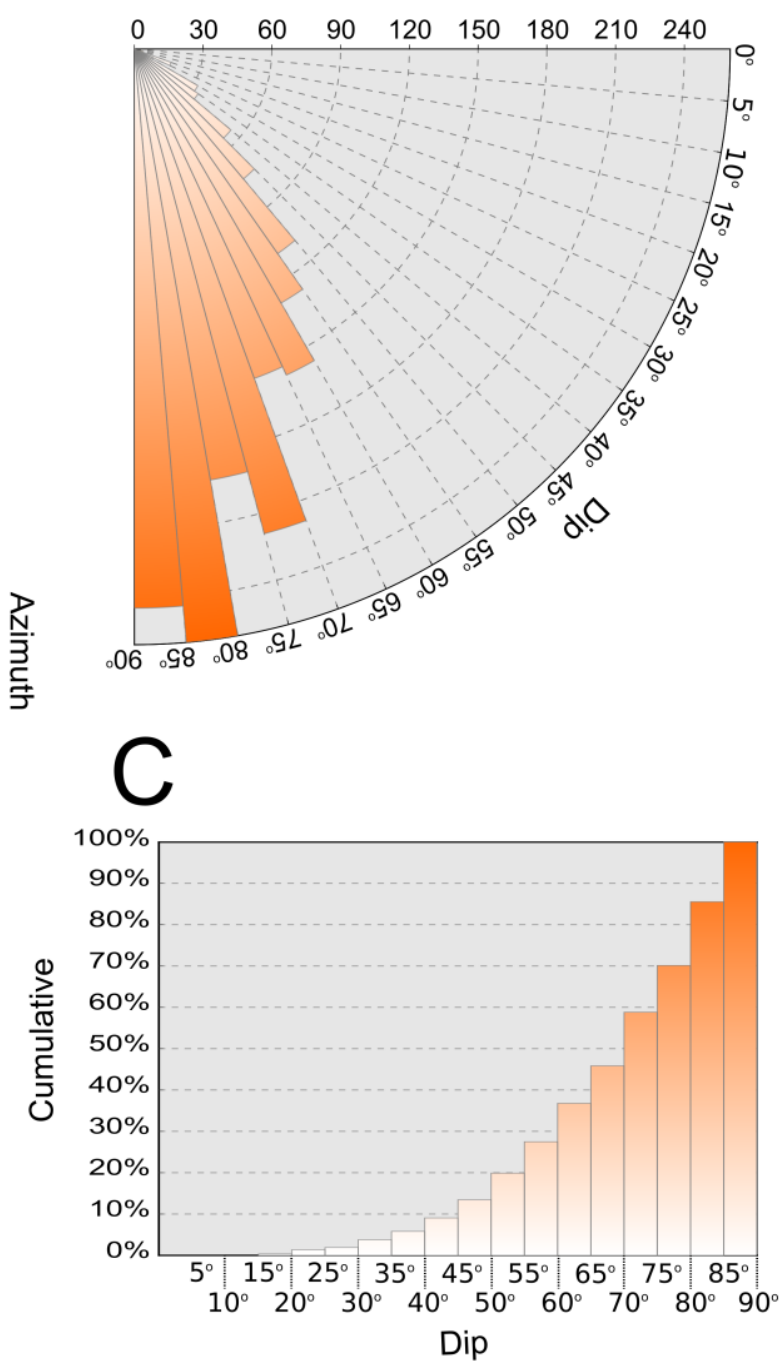




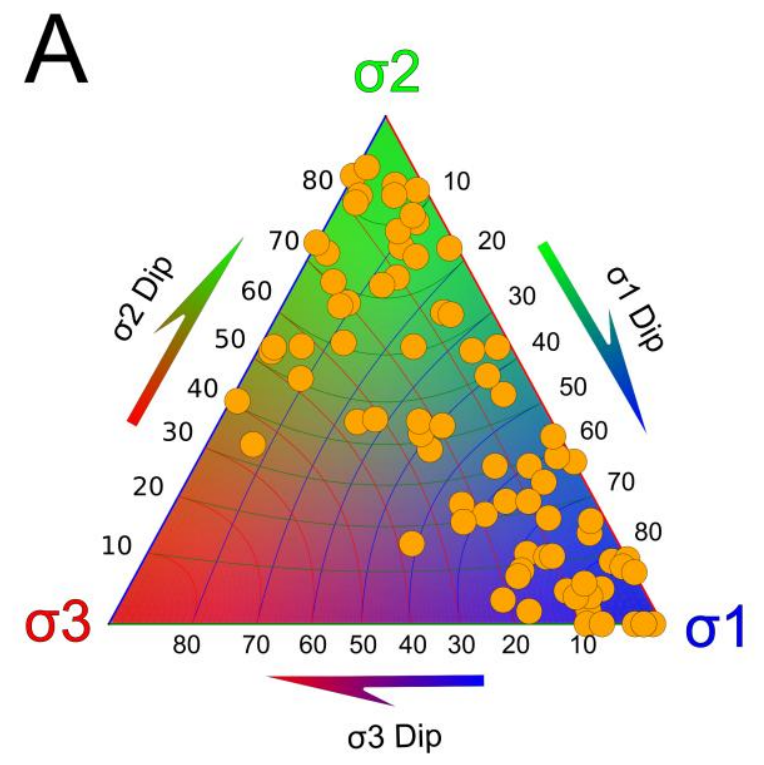

B

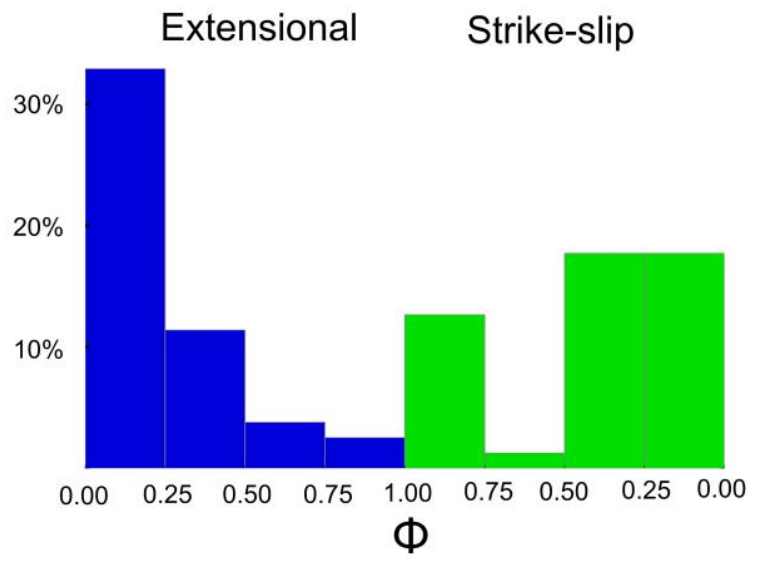



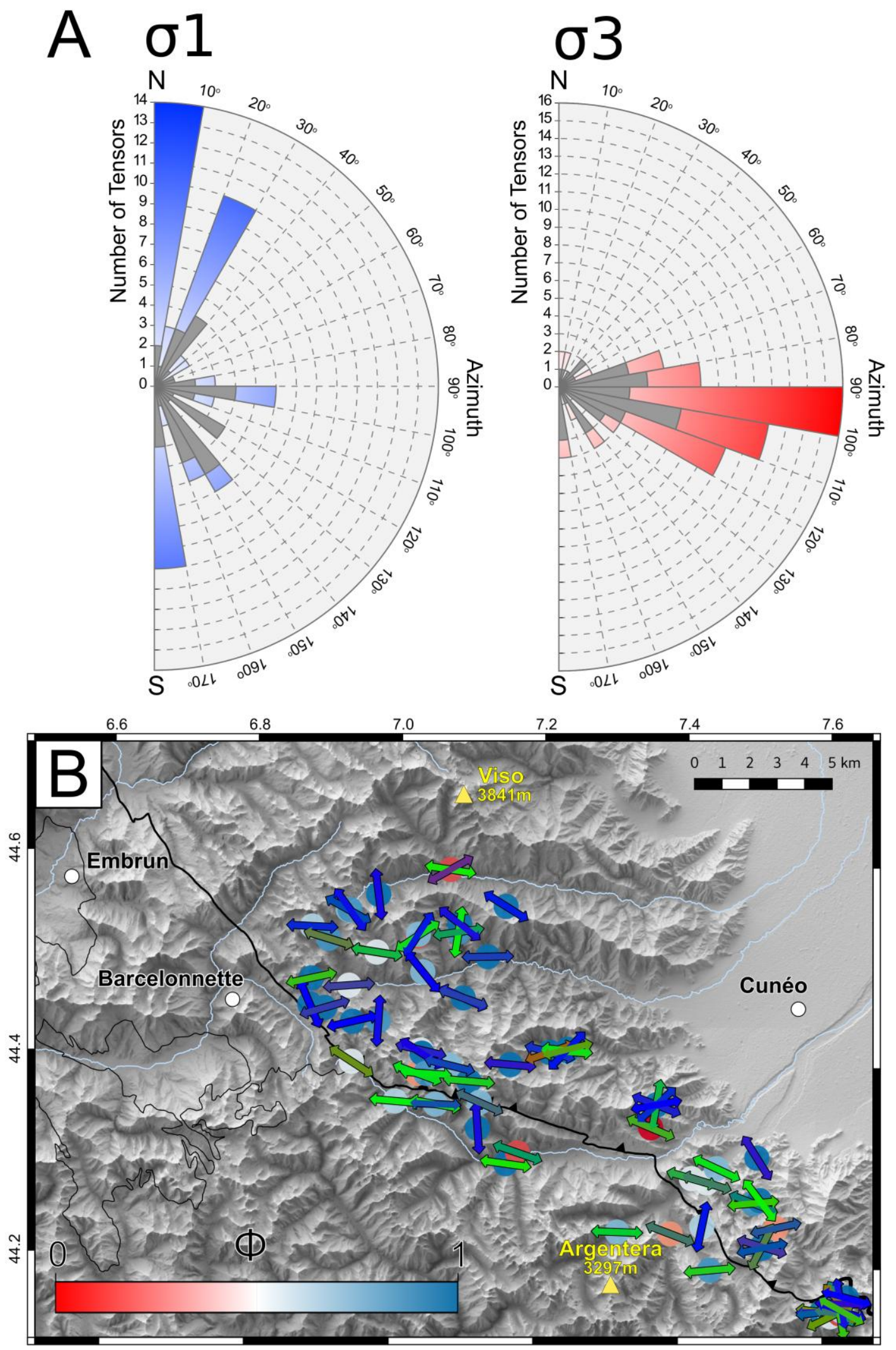


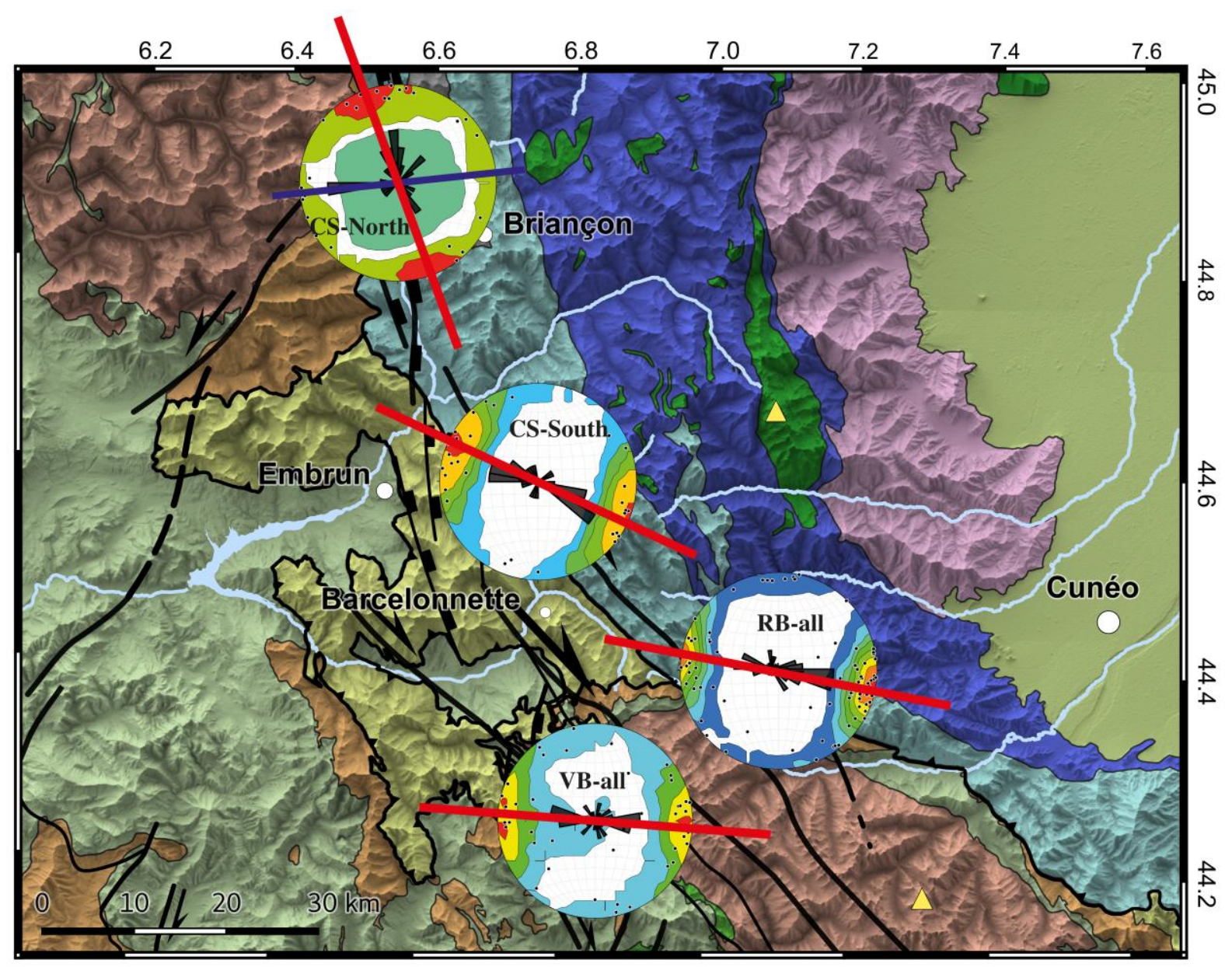




\section{University Library}

\section{- M M I N E R VA A gateway to Melbourne's research publications}

Minerva Access is the Institutional Repository of The University of Melbourne

Author/s:

Beucher, R;Sue, C;Tricart, P

Title:

Orogen-parallel brittle extension as a major tectonic imprint in the Neogene evolution of the south-western Alpine arc

Date:

2017-11-01

Citation:

Beucher, R., Sue, C. \& Tricart, P. (2017). Orogen-parallel brittle extension as a major tectonic imprint in the Neogene evolution of the south-western Alpine arc. International Journal of Earth Sciences, 106 (8), pp.2973-2990. https://doi.org/10.1007/s00531-017-1476-7.

Persistent Link:

http://hdl.handle.net/11343/282826 